\title{
PRIMATES IN PARADISE: CRITICAL POSSIBILITIES OF THE MILIEU MOVIE
}

\author{
Joel David \\ Inha University, South Korea \\ joeldavid@inha.ac.kr
}

\begin{abstract}
The use of multiple lead characters in cinema is a fairly recent development, although the strategy (and its resultant variety of structures) had been present for some time in theater and literature. The typical Classical Hollywood action-driven narrative operated most efficiently through a singular hero, allowing the audience to undergo the film experience via the process of singular identification. With the breakdown in identificatory requisites popularized by various New Wave and Third Cinema movements, and the consequent assimilation of this trend starting with the New American Cinema, mainstream Hollywood was ready to embark upon a series of multi-character movies, with Robert Altman's Nashville (1975) serving as watershed text. Interestingly, the production of films with multiple lead characters had been a long-standing staple in the national cinema of the Philippines-a country that itself holds multiple distinctions vis-à-vis the US, starting with its historical status as America's first (and only Asian) colony. This article will be looking at how a mode of practice that recently emerged on the global scene had been functioning in a relatively obscure national cinema, and how the practice ensured for itself a measure of longevity by distinguishing itself as a popular genre.

Keywords

milieu realism, multi-character films, Philippine cinema

About the author

Joel David completed his PhD in Cinema Studies at New York University, and is Associate Professor for Cultural Studies at Inha University in Korea. He was founding director at the University of the Philippines Film Institute. His book publications include The National Pastime, Wages of Cinema, and Fields of Vision (winner of the Manila Critics Circle's National Book Award), while his more recent articles have appeared in GLQ and Asian Journal of Women's Studies. In 2006, he coordinated the Whither the Orient film conference held in Gwangju.

\section{Author's note}

The author acknowledges the support provided by a faculty research grant from Inha University toward the completion of this paper. Earlier versions were presented at the University of the Philippines' Sangandaan International Conference and at Hallym University's 40th School of Communications Colloquium. Thanks are also owed to Ricardo Lee, Bliss Cua Lim, Violeda Acosta Umali, Theo Pie, Taeyun Yu, and the late Ishmael Bernal for many crucial insights, as well as the late film professor and historian Robert Sklar, adviser of the longer work on which this paper is based, and to whose memory this effort is dedicated.
\end{abstract}

May we agree that private life is irrelevant? Multiple, mixed, ambiguous at bestout of it we try to fashion the crystal clear, the singular, the absolute, and that is what is relevant; that is what matters.

- Hilary Stevens, in May Sarton's novel

Mrs. Stevens Hears the Mermaids Singing 
To me a single story seems like a very classical form, almost as if you're competing with the Greeks.

- Miranda July, dir. and scriptwriter Me and You and Everyone We Know (qtd. in Farber)

The use of multiple characters and multiple plotlines in narrative literature has been around arguably since the days of epic poets. Yet in modern popular literature this trend has been a comparatively recent development-as demonstrated in the attitudinal shift between the first and second quotes above-and such a latter-day emergence has also occurred in film practice. In fact a critical mass in popular American discourse may have arrived only since after the turn of the current millennium, first in 2005 with the best-picture Oscar upset by the multi-character movie Crash (Paul Haggis, dir. and co-scriptwriter), then in 2006 with the Oscar's life achievement award being handed out to Robert Altman, who specialized in the form, and whose peak achievement, Nashville, swept all the available major critics' prizes in its year of release (1975) but was cold-shouldered by the Academy in favor of a more conventionally plotted entry. As further proof that the multi-plot multi-character narrative had entrenched itself in mainstream American film culture, another sample, Alejandro González Iñárritu's Babel, was regarded as an Oscar frontrunner the year after Crash won.

Stephen Farber, best known for Outrageous Conduct, his account of the grisly accident that befell the 1982 shooting of the film version of The Twilight Zone, wrote a lengthy article for the New York Times in 2005 that heralded the triumphs of "movies with multiple story lines" and enumerated a number of recent and then-in-progress projects made in such a format. (The opening quote by Miranda July is from Farber's article.) The article runs through a number of possible descriptors and film samples for the multi-plot multi-character movie without suggesting which ones might be the most useful. ${ }^{1}$ It ends with a quote from Stephen Gaghan, scriptwriter of Traffic (Steven Soderbergh, dir.) and director-scriptwriter of Syriana, that attempts to explain, using a canonical authority, how audiences might find meaning, though not pleasure, in the format:

\footnotetext{
"Tolstoy said that the most important element in writing fiction is your ability to master transitions," Mr. Gaghan said. "That is the gift of multiple narratives. It turns out to be such a cinematic idea. You can cut from a radical cleric addressing disaffected young people to a massive yacht in the Mediterranean. There is a lot of power in those juxtapositions." (Farber) ${ }^{2}$
} 
Although a detailed history of "movies with multiple story lines" can be a productive endeavor in itself, this article can only supply a quick summary, following an urgent qualifier: a movie may contain either multiple plots or multiple characters, and the celebrated recent instances in Farber's article purport to uphold both multiple plots and multiple characters, but this article's interest would be multiple characters in singular plots (actually settings). To provide concrete examples: a film with multiple plots need not have several characters, as demonstrated in multiple-personality studies such as Nunnally Johnson's Three Faces of Eve and Daniel Petrie's Sybil, not to mention a wide variety of fantastic film-texts. On the other hand, movies in which the characters are set in sufficient proximity with one another so that they can interact physically, such as the aforementioned Nashville and Crash, may be definitely multiple-character but arguably single-plot. This will be the type of narrative format that will be pursued further in the article.

More unusually, the multiple-character movie will be considered from an entirely non-Western context, although its origins in American cinema will be acknowledged. The context being referred to is Philippine cinema, wherein the practice of multi-character film production acquired sufficient critical discourse and commercial popularity so that it became (and remains) a distinct local genre (Lee, interview). One further quirk in the course of this article's development will be a handful of self-references, inasmuch as the present author had actively participated in critical discussions (and occasional arguments) regarding the existence and validity of the form. Toward the end, questions crucial to a critical assessment of the practice of multi-character film production will be raised, although the article will be unable to provide final answers, inasmuch as the production of film samples is still ongoing and therefore cannot be subjected to a definitive historical assessment.

Rather than arguing that multi-character film production in the Philippines preceded that of the West, specifically the US, this paper will look at how trends in the emergence of such a mode of practice showed up in both places - first, as the prototypical presentation of a singular hero in a fairly large social milieu; then, in the transitional triangulated relationships (in effect a rejection of the singular heroic or the dual heroic/anti-heroic or heroic/romantic interest structure); and finally, in the deployment of a large number of characters, all with "lead" functions observing the narratological principle of resisting any tendency to focus on an individual character (or a pair of characters). In the final example, comprising a genuine multi-character film presentation with the potential of delineating a social milieu, the paper will demonstrate how this mode, after "arriving" in the Philippines via the influence of a major American film, Nashville, further developed by drawing from earlier studio traditions of packaging new performers in batches, resulting in a recognizable and distinct film genre. 


\section{ACROSS THE PACIFIC}

If the field of American cultural studies were to be reconfigured as topographic terrain, then postcolonial studies would constitute its jungle and the Philippines its heart of darkness - the unstable and ultimately unconscionable combination of science and myth that served to justify colonization while simultaneously masking, down to the present, any desire the occupation forces had for their erstwhile subjects, the primates who had to be made worthy of the paradise they existed in. The same factors that make the country such a challenging territory for scholarly conquest also supply the hazards that have tended to trip scholars on both sides of the Pacific. To open with the most distinctive claim that can be made for the country vis-à-vis its relations with the US: it is the only now politically sovereign state that ran the gantlet of relations, from colonial to neocolonial to postcolonial, that it shares with a number of other nations and territories (mostly in Latin America), but not in all facets. It may also be the only successful US colonial adventure in Asia, but then its history of resistance, though eventually suppressed, comprises its commonality with Vietnam, the US's only major colonial setback.

The Philippines' centuries-long endurance of European colonialism might suggest similarities with all the other countries affected by direct US occupation, but its links to other instances of anti-US resistance go earlier and deeper in that it serves as the historical and militaristic link between the US's exterminatory campaign against Native Americans and the war of colonization in Vietnam. ${ }^{3}$ The contestation of the extent of Philippine resistance is itself unresolved between the two entities: where US President Theodore Roosevelt declared the "insurrection" over four years after the Revolution Against Spain mutated into the Philippine-American War of 1898, the official history of the still-outlawed Communist Party of the Philippines describes the revolution as unfinished, citing American campaigns against banditry and religious fanaticism during the first half of the twentieth century and against "anti-democratic" forces (Communism and right-wing militarism) during the latter half as proof. ${ }^{4}$

The predicament this poses for Philippine scholars is so multi-pronged it's a wonder that some forms of nationalist scholarship persist at all. Where discourses and strategies of development have been led (and monopolized) by Euro-American spheres of influence, the highest stage of such development is indubitably commanded at the moment by the Filipino nationalists' historical and material enemy. ${ }^{5}$ How then to fashion an anti- or counter- or alterna-discourse that would prove fruitful for the purposes of nationalist development, when the best available tried-and-tested tools were originally used by an entity operating in direct negation of Philippine concerns?

Before this question can even be raised, the articulation of the shape and nature of the Philippines' interests has to be accomplished. What this requires of the Philippine nationalist 
scholar, as it does of Third-World scholars in general, is the formation of levels of expertise in radically opposed realms - East/West, South/North, premodern/modern, underdeveloped/ developed, etc. - within terms that do not always-already impinge on the Western scholar. Caroline S. Hau explains further ${ }^{6}$ that

Political struggles, therefore, implicitly commit themselves to the idea of the epistemic reliability of intellectual praxis, to the possibility of obtaining accurate and reliable accounts of the world (or of a particular society) that can help demystify existing institutions and their systems of oppression. In other words, to the extent that it is about forging epistemically reliable accounts of the people's hopes, visions and experiences, sound intellectual praxis is a necessary component of sound political praxis. (3-4)

\section{CINEMATTER}

The study of Philippine cinema falls within the scope and range of these controversies. The best known case is that of Marxist American author Fredric Jameson, who gave preeminence in his book The Geopolitical Aesthetic to a film that made waves in the international festival and distribution circuits during the late seventies but which has remained little-seen in the Philippines, and whose director had earlier been disparaging of the Philippine popular-film mainstream (186-213). ${ }^{7}$ Philippine cinema deserves more attention than it has received so far, and the numbers only begin to tell the story: film screenings in the country are now widely accepted as having started in 1897 , and indigenous production has grown from two in 1919 through double-digit figures in the 1930s (understandably dipping during the Japanese occupation) and hitting triple-digit figures from the sixties onward (Del Mundo, "Philippine Cinema" 31-55). Although introduced by European entrepreneurs during the eve of the Spanish occupation, the motive for the continuing growth, it turns out, was more effective control by the Spaniards' replacement, the Americans - a recognition of the medium's biopolitical potential that preceded Vladimir Lenin's policy declaration after the Russian Revolution, but for distinctively counter-revolutionary ends. ${ }^{9}$

Since foreign exposure virtually dried up during the nineties after the death of Lino Brocka, and before the still-recent reintroduction of digital films to the global festival circuit, the country's population had become its cinema's only market. The resulting annual per-capita figure up to the mid-1990s, based on an average of 150 movies being released for a population of about 70-80 million, points to a comparably more active level of activity than, say, India's 800 films for 700-800 
million, when an equivalent proportion of activity for both countries should place either Philippine production at less than a hundred or that of India at nearly twice its already record output.

More-than-casual observations on Philippine cinema ought therefore to turn on the expected issues of representations of the national, but within the reflexive social framework of the Other viewing her Self onscreen. The way this principle has been realized, in Philippine film practice, was through a proliferation of films with multiple lead characters, to the point where commercial strategies that were launched during the late sixties were refined and disseminated during the martial law period of the seventies and early eighties. That the regime of then-President Ferdinand E. Marcos, during which most of these films were produced, regarded a number of these films as censorable speaks not only of their impact on the moviegoing audience but also of their importance as a mode of practice for politicized filmmakers.

Although the filmic element that defines the genre in question is narratological in nature, not much can be found in theoretical studies on film narrative that deal with the question of the multiplicity of character. Contemporary narratology, in taking the structuralist cue from Roland Barthes's cautionary appraisal of character as in danger of being privileged over narrative, has tended to acknowledge the paucity of material concerning the question of character. ${ }^{10}$ In "Introduction to the Structural Analysis of Narratives" (hereafter "Structural Analysis"), Barthes critiques the valorizing of character in New Criticism as "an individual, a 'person,' in short a fully constituted 'being"' who "stopped being subordinate to the action, embodied immediately psychological essences" (104); he describes this modification as an attempt to step forward from the notion of character in Aristotelian poetics as "secondary, entirely subsidiary to the notion of action: there may be actions without 'characters' ... but not characters without an action" (105). Barthes upholds structural analysis" "utmost reluctance to treat the character as an essence, even merely for purposes of classification" (105), and points out the futility of privileging a "class of actors" by citing as an example the existence in many narratives of

two adversaries in conflict over some stake; the subject is then truly double, not reducible further by substitution. Indeed, this is even perhaps a common archaic form, as though narrative, after the fashion of certain languages, had also known a dual of persons.... If therefore a privileged class of actors is retained (the subject of the quest, of the desire, of the action), it needs at least to be made more flexible by bringing that actant under the very categories of the grammatical (and not psychological) person. ("Structural Analysis" 108-09) 
Although Barthes subsequently modified his position on character (notably in $S / Z$ ), it is his formulation of the problem of how character may be created in the text in the fuller "Structural Analysis of Narratives" essay that may prove more fruitful for exploration. ${ }^{11}$

One can therefore bring together two normatively non-relatable areas of study, a fairly unexplored formulary in film narrative practice and an even less-explored specific instance of a national cinema. This manner of articulation might appear to present the usual advantage of having a node (narrativity) that helps open out the topic into other areas (other national cinemas, for example), while at the same time exploiting a highly specific cultural context (martial lawera cinema in the Philippines) that ensures a measure of rootedness for the study. My concerns, however, are more specific and overdetermined at the same time: not only is Philippine cinema, as are all the Third World cinemas I have encountered seem so far, cosmopolitan in many of its phases and aspirations, but the issue of narrative therein has also maintained a pointedly and primarily social dimension. ${ }^{12}$

\section{REGARDING FORM}

As already mentioned in the beginning of this paper, the existence of multiple lead characters in individual films has been recognized by observers and commentators in a number of titles from the seventies, notably those of Robert Altman. ${ }^{13}$ A renewed proliferation of multiple lead characters had subsequently been spotted by reviewers writing about so-called American independent productions. ${ }^{14}$ While the present study might be able to lend itself to speculating on why mainstream seventies and independent nineties American cinema exhibit this tendency toward using several lines of character-based action, one will have to delimit the scope of observation to how the American samples, specifically Altman's Nashville (1975), impacted on Philippine film practice.

As far as pre-'90s analytical writings go, however, only two texts make extensive mention of multiple characters in movies, both dealing with the New American Cinema and its aftermath. Of these two, one, Robin Wood's Hollywood From Vietnam to Reagan, regards the "multi-plot, multicharacter structure" with suspicion by associating it in one instance with disaster films and in another instance with the eighties "high school cycle" teen pic $(29,216)$. Wood's critical devaluation of Nashville proceeds from his regard of the city of Nashville itself as "an image of America, though much more pessimistically conceived, with the notion of survival ... become bitterly ironic" (29). He then runs through a series of other movies and concludes that Altman relies on a "Smart-Ass and Cutie-Pie" principle (the same title of the chapter itself, drawn from a diegetical description of the Marlowe character in Altman's The Long Goodbye [1973]), which he defines as the use of 
antagonizing and disarming elements as artistic strategies (38). Returning to a consideration of Nashville, he concludes that "The film's total effect-for all the marvelous local successes - is to engulf the spectator in its movement of disintegration, making intellectual distance impossible" (41). In a chapter titled "Images and Women," Wood turns to the aforementioned eighties high school cycle, of which he qualifies parenthetically that "the obvious touchstones are George Lucas' American Graffiti (1973) and Bob Clark's Porky's (1981), respectively its pre-eighties initiation and its most fully representative eighties manifestation" (215). He enumerates five characteristics of the genre, comprising the "commodification of sex in contemporary capitalist culture," the "almost total absence of parents," the "initiation of the male virgin," "the repression of homosexuality," and, regarding "multi-character movies," the remark that "The aim is to reach and satisfy as wide a youth audience as possible; there must, therefore, be a range of identification figures, and no minority group (with one significant exception) must be entirely neglected (though arranged within a careful hierarchy)" (215-16).

While certain of Wood's insights may be arguably valid within the terms of his analysis, his insistence on a narrow ideological stance has effectively allowed him to override the requisite of looking into the formal and structural properties of the objects of his study. His assumption as well that the mere mention of multiple characters in movies need not be elaborated upon can be seen as an indication of how the phenomenon could be perceived and noted in critical writing, yet at the same time regarded as subordinate to the larger question of the historical precedence of older genres. In effect, multi-character movies, as per this view, could not constitute a genre unto themselves (regardless of the more basic principle of generic classification in literature where form is fundamental), but the inevitably commercial motive in casting a large number of stars in a single project allows an older generic framework to take hold. ${ }^{15}$

The other text that takes notice of multiple characters has gone farther in attempting to evaluate what its authors labeled the "group film." The particularities of Michael Ryan and Douglas Kellner's Camera Politica's consideration of progressive film form commences with their setting up of an opposition between metaphor and metonymy as related filmic rhetorical strategies (312). ${ }^{16}$ Within this binary, Ryan and Kellner maintain that metaphor, in referring to a vertical axis of presentation, tends toward an idealizing schema, while metonymy, because of its horizontal structure and materializing effect, lends itself to more politically expedient ends (313). Nashville, in its refusal to collapse onto the singular hero or dual hero/antihero mode of presentation, promotes the materializing principle and can therefore be seen as a sample of a progressive film text (see Figure 1). The multiple-character format in this respect can be linked with a number of other features that enable the spectator to regard a film text metonymically: open-endedness, distantiation, generic playfulness, and demythologization within mainstream film undertakings (269-82). 

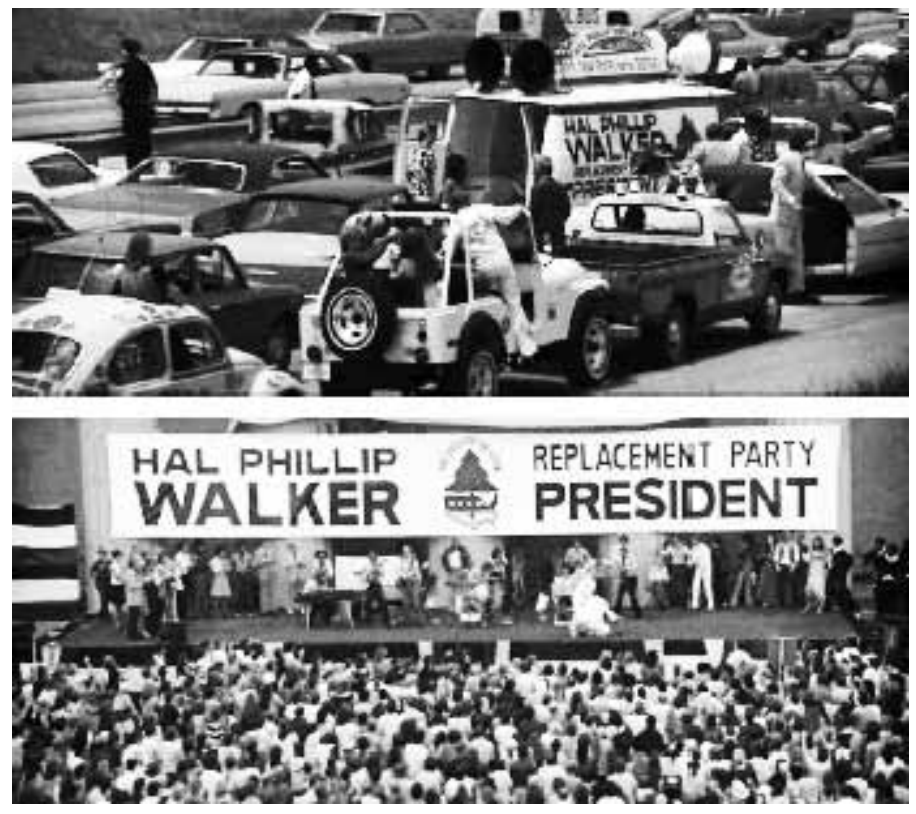

Figure 1

Disaster film, progressive text, or both? Car pile-up and outdoor concert assassination in Nashville. MGM DVD, screen captures by author.

Two short studies that can be related to the present one deal with multiple characters, but only implicitly. In opening his essay "The Compound Genre Film," Adam Knee echoes this literature survey's lament by stating that "Although it is commonplace to note the proliferation of varied genre combinations in commercial films of the eighties, the notion of what, precisely, constitutes and characterizes a compound genre film has been very little discussed" (141). He differentiates this type of work from two other related types of mixed-genre products: the genre hybrid, an organically derived entity in which two or more sets of generic conventions have somehow become one; and the subgenre, the seemingly natural development within one genre of certain characteristics which happen to be shared by another genre (141). The compound genre itself is defined by Knee as a type of film "that concurrently engages multiple distinct and relatively autonomous horizons of generic expectation; the extent to which these horizons remain distinct is the extent to which we perceive the text as being compound in its generic nature" (142). Knee mentions an "inescapable level of self-consciousness" as the most important corollary of multiple generic affinities, stating that "when two or more sets of generic expectations are thrust together, each one immediately becomes a marked element, and a new level of discourse is of necessity opened up" (142). His essay posits the existence of two possible paradigms for the compound genre, one wherein the multiplicity of generic voices remains intact and the other 
wherein discursive tensions are nullified through a final large-scale condensation, equatable with a "traditional unified resolution" (142). This consideration of the possibility of generic multiplicity within a singular film text can be related to the original possibility of character multiplicity, and in fact it will be possible to demonstrate how a carefully conceived and expertly executed multiplecharacter sample can assume more than the expected compound-generic properties by allowing each character to carry, so to speak, a recognizable and distinct filmic genre on her own.

In "Multiple Narrative Structures in Contemporary Cinema," Dan Hassler-Forest, like Knee, asserts that "no theoretical work has yet been done that seriously analyzes how these very films construct a single meaning from three or four separate narratives," and criticizes the manner in which influential film scholars have been dismissive of such constructions. Although HasslerForest's emphasis on narrative, rather than character, leads him to undervalue multiple-character films that contain "a narrative event that combines the characters," preferring instead texts whose narratives' causalities do not imbricate one another, his study proffers a comprehensive attempt at categorizing the various forms and possibilities of multiple narrative structures. Certain of his claims and methods resemble a few of what I had already laid out in earlier essays on the multiplecharacter format (David, The National Pastime 169-71; Fields of Vision 31-33; Wages of Cinema 1425), but Hassler-Forest's direction in tackling the individual subgenres leads to a valorization of independent narrative strands, while the present study will attempt to uphold the primacy of a single narrative that happens to contain several characters.

The seeming interchangeability of the terms "format" and "genre" will need some clarification at this point. Primarily used to refer to film gauges and technological modes, format is also utilized as a means of signifying literary intention (as in the fictional format or the television format), with generic classification an incidental and only occasional result (as in the documentary format). Genre indicates an awareness of a body of principles, whether drawn from a format, a style, an industrial or spectatorial requirement, or (more commonly) combinations thereof. Multiple-character film practice was, and still is, a genre in the Philippines, with its own native coinage, "milieu realism"; it is not regarded as such elsewhere, although the format is certainly readily identifiable. Hence the term "multiple-character format" may be used to indicate the formal properties of the practice, while "multiple-character genre" can denote the practical dimension that emerged and flourished in the Filipino film industry.

\section{REGARDING CONTEXT}

In the fairly recent period since the observation that "no history - in the traditional comprehensive, definitive, and authoritative senses-of Philippine cinema exists, even as the 
centennial of the near-simultaneous invention of film and its intervention in Philippine history approaches" was made (David, Wages of Cinema 114-15), ${ }^{17}$ an article supplying a serviceable outline of Philippine cinema was published, devoid of the usual personal and institutional biases and agenda that tended to skew or obstruct previous attempts at unfolding a long-untold story. Clodualdo A. del Mundo's "Philippine Cinema: An Historical Overview” periodizes local film history not in terms of either the high points of concentrated artistic accomplishments or the minute arbitrary segmentations of the typically over-involved Filipino film historian. ${ }^{18}$ Del Mundo instead adopts the generationally determined divisions now standard in studies of Third Cinema, with each generation lasting twenty years or more, resulting in the current crop of practitioners being calculated as belonging to the fourth, thus: 1920s to early 1940s, First Generation; mid-1940s (presumably excluding the Japanese occupation) to 1960s, Second Generation; 1970s to 1990s, Third Generation; and late 1990s to the present, Fourth Generation (30-57). Although still echoing the anti-mainstream slant and tending to observe "Golden Age" periodizations along with the requisite enumeration of canonical titles, Del Mundo underlays his account with a basic empirical presentation of tabulations drawn from existing filmographies and underscores the salient political and institutional features of each period.

Within the concerns of the current study, Del Mundo's "Overview" shares two fundamental lacks with previous histories (or, more accurately, historicizations) of Philippine cinema. First is its oversight of the role played by foreign cinema, especially Hollywood (cf. Higson) - a daunting but thoroughly essential challenge for the US's only ex-/neo-/post-colony. Second, relatable to the first, is its implicit disavowal of the study of the formal properties of the national cinema itself, as if the ideals of formal innovation and exploitation were unattainable outside a First-World context.

Del Mundo's case, however, can be seen as the culmination of an attempt to move away from this avoidance of formal discourse, ironically by moving further back into a historical past in order to anchor the discussion in an older art form. In his book Native Resistance, he draws extensively from critical essays written during the seventies by University of the Philippines-based members of the Manunuri ng Pelikulang Pilipino (Filipino Film Critics Circle) that ascribe the formal and narratological properties of popular Filipino movies to theater traditions such as the pasyon (based on the agonies of Christ), the komedya (also known by the now-offensive term moromoro, based on the subjugation of non-Christian, especially Islamic, populations), and the sarswela (based on nationalistic musical romances). ${ }^{19}$ The approach has been criticized for the conspicuous pitfall of reading one medium within the formal and historical framework of another, and worse:

such qualities of the komedya and the sarswela are not independent in themselves nor are they solely reflective of the Filipino sensibility, but arose out of ... centuries- 
old feudal structures.... Finally, theater, while it is not inimical to cinema, can be retrogressive to the development of the latter if we are to continually take theater into account in viewing our cinema. (Guillermo 98)

While it may be counter-argued that the pro-theater essays actually refused to endorse, and in fact cautioned against, a continuing reliance on old theater forms, the more basic difficulty of conceding the influence of traditional theater on contemporary cinema lies precisely in the same complex that hinders the utilization of methods deemed inappropriate to a system underdeveloped in relation to the colonizing center. This complex, which we might provisionally call the postcolonial mentality, partakes of the aspect of colonial mentality that regards products and ideas originating from the center superior to those that take root in the colonized space. The departure from colonial mentality is that, with the intervention of a nationalist ethos, such an attitude of inferiority becomes an embarrassment to the colonized subject, thus requiring a measure of repression usually through the display of aggression against an object perceived as unworthy yet reformable. Postcolonial mentality materializes when the said subject contends merely with the unacceptability of her feelings of lack, and devises as a coping mechanism the resort to critical introspection without applying the same critical faculties to items from and by the colonizing center.

This principle can be seen in how the pro-theater angle actually winds up explaining away what the authors implicitly agree are indications of inferiority in local films vis-à-vis those from Hollywood. Filipino film writers who have taken up the poststructuralist enterprise may have bought into the movement's emancipatory promises of decentralized and unfettered critiques of everyday issues, yet the manner in which postcolonial mentalities have insinuated themselves has yielded even worse predicaments than the period when expressions of inadequacies were more openly admitted. Typically, the native poststructuralist practitioner would latch onto a foreignderived theoretical framework, hold up a local sample to it, and evaluate the sample without taking note of how the framework may have arisen in a different situation implicated by a unique set of personal and institutional interests, much less acknowledging that the formulation of the framework itself might be deficient for the sample in question. The fact that the poststructuralist notion discourages canon-affirming conclusions merely exacerbates the recognition by local critical practitioners of non-local sources' superiority by driving it below the discursive surface of their arguments. ${ }^{20}$

Del Mundo's book, though unable to bypass these debilitating tendencies, compensates in large measure by positing native resistance within culture (as per its title) as the means by which the Filipino nation managed the terms of its defeat in the unjust and savage (and generally 
overlooked) Filipino-American War and its disastrous aftermaths. Del Mundo delimited his area of application to the cultural products in question, specifically the only three still-existing preWorld War II movies, all of which were decidedly generic in form and intention. Not surprisingly, he was unable to find in these film-texts enough of an intervention to make a claim for a definitive discovery for or against the presence of "native resistance" in this much-contested aspect of local popular culture. ${ }^{21}$ Although my reading strategy will differ significantly from his in that mine will be looking at culture not through local artifacts per se but through the ideological rhetoric inhering in those products, the concept of resistance through the use of available industrial and human technologies, even through those directly furnished, mandated, and propagated by the occupying forces, will underlie the rest of the study, as it did Del Mundo's.

What this approach necessarily entails is that the cultural studies aspect of Del Mundo's project will be more overtly and consciously pursued in this study. While formal analyses will be crucial to the consideration of the ontology of the multiple-character film-text, issues of production and reception will also be tackled in order to situate the practice within the Philippines' national and Philippine cinema's industrial imaginaries. ${ }^{22}$

\section{MEDIATIONS}

By making use of a generic formation based on strictly narrational properties, one can return to certain concerns in film studies that were attempted in the past but abandoned for want of sufficiently productive results - roads not taken, as it were. Within film genre theory, the conventions, in the sense used by Andrew Tudor, ought to remain, as emphasized, narrational, specifically character- and action-based, rather than image- or incident-based (121). This would align the approach not just with form-based methods of classifying movies (e.g., abstract films, documentaries, animation, structural-materialist cinema, etc., as opposed to Westerns, gangster films, melodramas, horror films, etc.) but also with the more traditional and basic means of categorizing literature-i.e., poetry, the novel, drama, the essay, etc. ${ }^{23}$

The condition of the "empiricist dilemma," as described by Tudor, wherein genre experts would require proof of the existence of certain criteria, but where such criteria have to be derivable from already existing instances as confirmed in viewership practice (Tudor 121), applies - but only as a challenge, no longer as a condition. In other words, although the origins of the multiplecharacter genre can be traced, at least within the terms of this study so far, from American sources (where it remains unnamed as a genre) and in Philippine practice, the fact that its properties are reducible to certain basic literary elements in film production explains how it can be identified even in the places where it has not been recognized. The challenge for the critic then lies in teasing 
out the strands involved in the emergence of the text in order to explain why the imperative for resorting to such a narrational structure became strong enough to override the universal featurefilm standard heroic or variant heroic/anti-heroic or heroic/romantic-interest models. (In fact a distinguishing feature of the genre is the unusual demands it makes on mainstream commercial practice-non-linear script formulation, disintegration of star-based arrangements through the multiplicity of performers, complex and minute adjustments in physical and temporal narrative suturing, and so on.)

The other road not taken would refer, briefly put, to the historical abandonment of the social realist project by progressive artists in cinema, way before the collapse of the Soviet bloc-as early possibly as the enforcement of the prescriptions of socialist realism in the cultural practice of what was then known as the Second World. The facts that the dogmatic excesses of the social-realist policy did not effectively result in the depiction of social realities beyond what proved useful to state ideologues and that celebrated instances of social or realist cinema were released outside the sphere of "socialist" dominance both contributed to progressive artists' eventual disillusionment with the quest for a workable mode of social realism, much less a totalizing one.

A contemporary film scholar could therefore device a qualifiable insertion into such a longabandoned concern, in that, in an extremely, almost embarrassingly, literal sense, the multiplecharacter format, when successfully executed, facilitates the depiction of a society comprising the (presumably interacting) lead characters in the filmic narrative. That the terms of realism will be crucial to the perception of such a system at work would enable such a study to stake a claim as a recognition of a productive formal means of upholding and applying some of the more elementary tenets of social realism, specifically the call to replicate as faithfully as possible the appearance and operation of the dynamics of social relations (Christie 4$){ }^{24}$

\section{MANNERS AND ISMS}

One can also productively proceed from the polemic of the multiple-character movie as a valid generic type, with the necessary qualification that "character" in this instance denotes lead performances, and that "multiple" refers to a minimum of three. ${ }^{25}$ On occasion, when the use of multiple lead characters in film is referred to as a "format," its generic attributes, recognized or not, are subsumed under non-genre considerations or super-genre issues, as when Nashville, a multiplecharacter movie, gets classified as one or the other of a number of traditional genres.

The study of multi-character films can therefore be structured according to a taxonomic breakdown of the possible permutations of the genre, as represented in each instance by one or more film samples. The use of the classificatory principle of taxonomy is more than just pragmatic, 
since such films evince not only a rudimentary historical progression of the multiple-character format, but also an increasing valorization of the available models. The study's contribution to what may be the earliest and most basic concern of film studies, that of formalist discovery and elucidation, rests on this organization of ideas.

A number of factors can be marshaled as possible explanations for the receptiveness of Filipino movie-goers toward multiple lead-character film presentations. One, perhaps too literal, observation would be the close resemblance in the Philippines between film theaters and Spanishera Catholic churches. For local audiences to look front and upward while seated in rows in regular attendance, one need only replace altars with screens in order to complete the analogy. The element of multiplicity comes in when we consider the spectacle available in the major traditional churches: the retablos, or altar pieces, where "the foci were the niches containing the santos [icons of the saints]" (Javellana 156; cf. Figure 2). True to the global supremacy of Classical Hollywood cinema, Philippine films prior to the Second Golden Age of roughly the martial-law years under the dictatorship of Ferdinand Marcos also featured singular heroes; yet the more ambitious among these tended to develop their lead characters as social heroes, constantly interacting with one or more secondary characters throughout the text. In one representative sample, Gregorio Fernandez's Malvarosa (1958), the hero is the only woman in a large lower-class urban family who winds up performing parental functions for her temperamental, abusive, weak, and/or criminally inclined male siblings. Though currently considered by film observers to belong to the "prestige" rather than the commercialist camp of the 1950s first Golden Age whence it originated, Malvarosa actually breaks out of either mold in that it utilizes generic elements - melodramatic developments, action sequences, fantastic coincidences, contemporaneous humor and lingo-in the service of a slumset narrative that, more important, promotes an unusual empathy with undesirable social types (the murderer, the pimp, the polygamist, the rapist) through the then-also-unusual strategy of identification with a female character (Figure 3). The fact that, within the ideal of classical unities, the narrative is fractured via its detours through the stories of peripheral characters serves to disrupt, among other things, the process of singular-character identification. ${ }^{26}$ And finally, although the avowal of the hero in Malvarosa is to rise above her station one way or another, the movie's downbeat resolution "flattens" her heroism, in a manner of speaking, in a way that favors and augments social insight.

By the arrival of the Second Golden Age (1975-86; see David, The National Pastime 3-8), production processes that served to prime audiences for multiple-character presentations were firmly in place, often with resounding popularity. The prototype was set by Sampaguita Pictures, which had garnered long-term political mileage by producing romanticized biographical pictures exploited by Marcos for his presidential campaign and which subsequently promoted a set of 


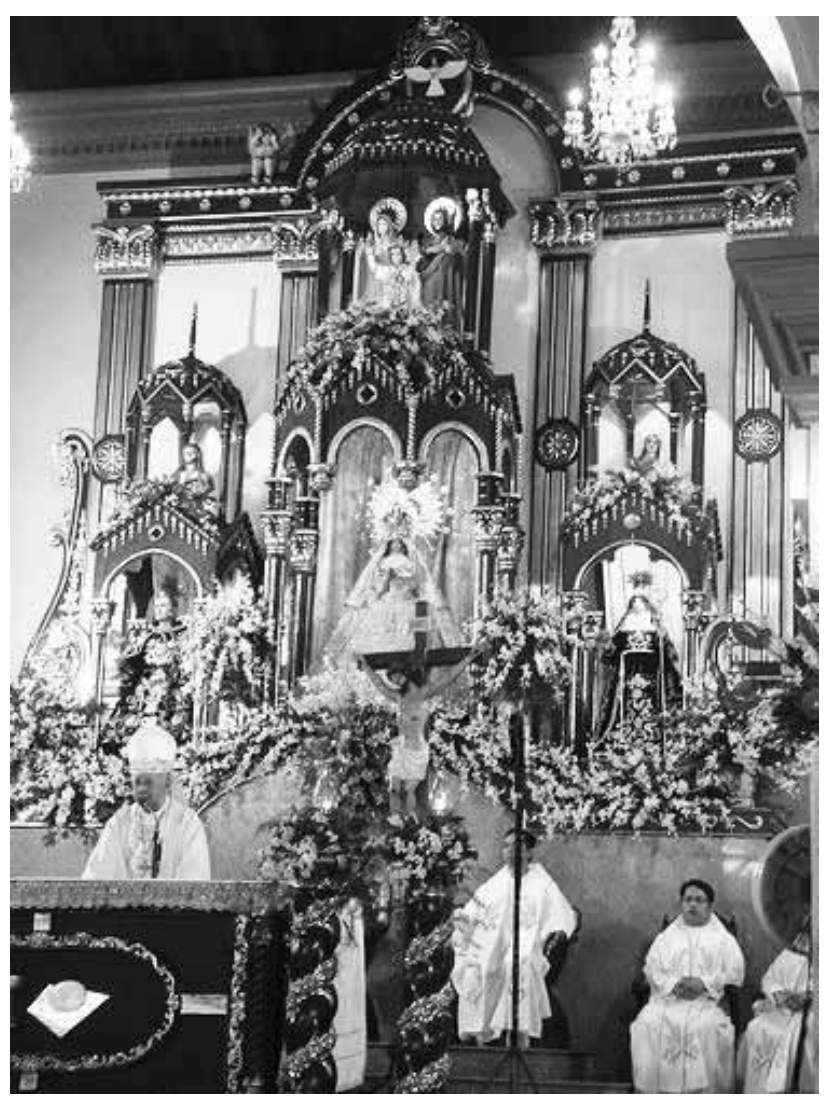

Figure 2

Retablo at Obando Church, taken during the district's 2008 fiesta. Photo courtesy of Custodia Virgo Salambao, used with permission.

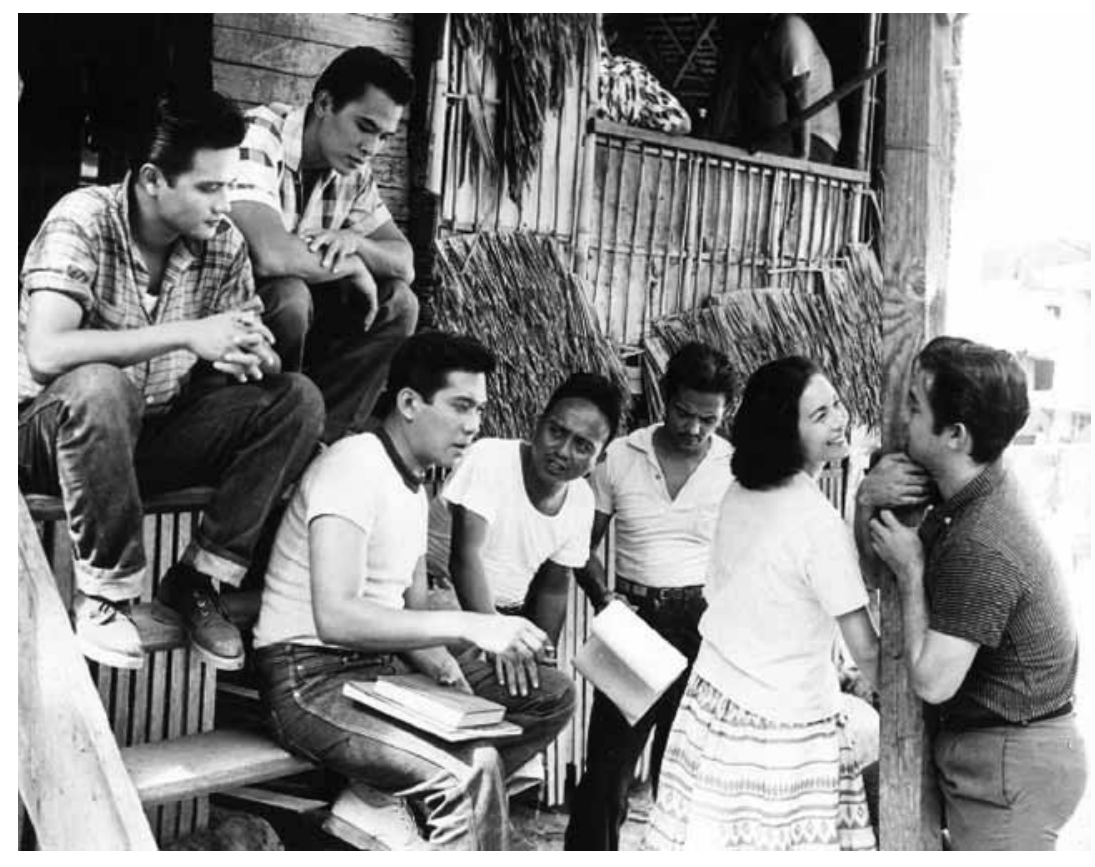

Figure 3

Rehearsal for a scene between Rosa and her brothers (plus boyfriend) in Malvarosa.

Still courtesy of the Lopez Memorial Museum Photo Archive, used with permission. 
new faces, five men and five women, collectively known as Stars '66 (referring to the year of their launch). One of the unarticulated objectives of the arrangement was to maximize the potential of what was then termed the smorgasbord movie, wherein a production would compensate for the absence of one or two major stars by hiring instead a large number of minor ones. This was the period of apprenticeship of the two most famous filmmakers of the Second Golden Age, Lino Brocka and Ishmael Bernal. With the local release of Nashville in 1976, both directors rushed to produce similarly structured projects, with differing and defining results: Brocka's was commercially successful but critically derided, ${ }^{27}$ while Bernal's, a commercial flop (mainly because it was bigger budgeted), remains one of the most acclaimed local releases. The film, Nunal sa Tubig (Mole on the Water, 1976), provides the minimum number of characters for a presentation that may be defined as multiple: three, rather than the singular hero or dual hero-antihero or hero-love interest that typified classical film texts. Although the three characters in Nunal sa Tubig were set in what may be an unstable arrangement, a love triangle, Bernal maintained the primacy of the roles of the two women sharing the same man by having the lead male character leave the setting (a small fishing village facing the encroachment of industrial modernity) for about a third of the narrative.

An even more successful multi-character Bernal film was Aliw (Pleasure, 1979), where the lead triumvirate comprised female sex workers (see Figure 4 for samples of Bernal's triplecharacter films). Aliw was produced by Seven Stars (the resurrected version of Crown Seven, which had collapsed after the financial failure of Nunal sa Tubig), an independent company specializing in attractive and talented women performers; one of its unrealized Bernal projects in fact was a film titled after its group of stars, Siete Belyas ("seven beauties," from the Spanish, although belya in Filipino also means prostitute). This strategy of packaging female performers according to identifiable batches reached fever pitch during the period of protest that followed the assassination of Marcos' political rival, former Senator Benigno S. Aquino, and that culminated in the peoplepower revolt that ended the dictatorship. Some examples, who achieved notoriety by appearing in the hard-core sex films that the Marcos regime allowed to proliferate during this period, as a possible means of distracting the public, were the Softdrink Beauties (whose members' names were adjusted accordingly, such as Pepsi Paloma and Coca Nicolas), the Hard-Drink Beauties (e.g. Remy Martin, Chivas Regal), the Street Beauties (e.g. Ayala Boulevard and, after Manila's Jones Bridge, Bridget Jones), and the Revolutionary Beauties, named after prominent participants during the people-power uprising (David, “The Fantasy World of Rey de la Cruz” 14).

With the triumph of Aliw, Bernal was prepared to undertake his most ambitious project. Up to this point, he had been tinkering mainly with the dynamics of the triple-character film, usually triangulations of desire. Aside from Nunal sa Tubig, he had a few other major love-triangle 


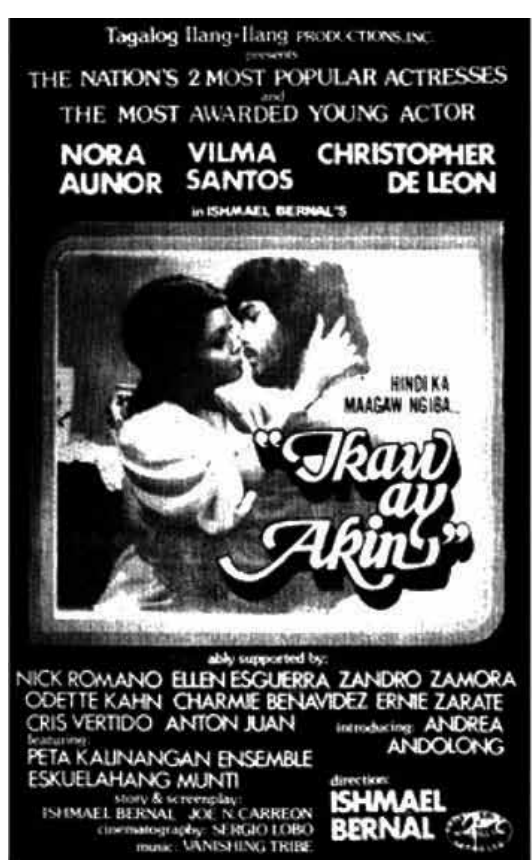

\section{MGA BABANG BIKTMAL...}

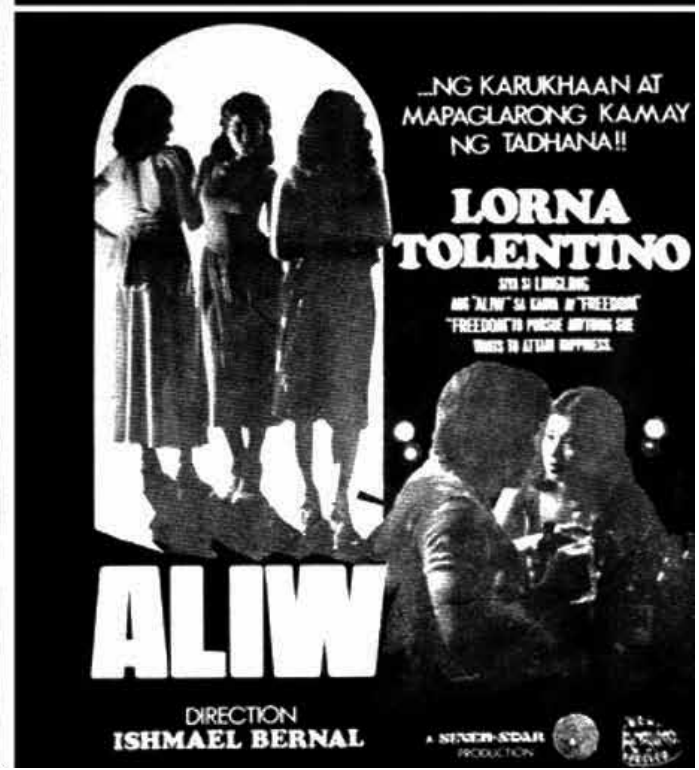

Figure 4

Triple-character films by Ishmael Bernal: male-centered love triangle in Ikaw ay Akin; women-focused triangle in Nunal sa Tubig; equal-emphasis triumvirate of female sex workers in Aliw. Newspaper ad layouts posted online by Video 48 weblog, used with permission.

narratives, notably the star vehicles Dalawang Pugad, Isang Ibon (Two Nests, One Bird, 1977) and Ikaw Ay Akin (You Are Mine, 1978). After dispensing with erotic relations among the three main characters in Aliw, he proceeded with a far more commercial (and consequently critically overlooked) exercise, Menor de Edad (Underage, 1979), with a slightly larger number of characters (five instead of three) but maintaining the emphasis on women-only leads. The commercial success of the last two films enabled the Nunal sa Tubig producer, Jesse Ejercito, to re-establish his renamed production outfit, and emboldened Bernal to devise a large, diverse, sprawling, contentiously interacting cast of characters, the closest so far to the sample that Nashville embodied.

Serendipitously, Regal Films, then recently emerged and destined to be the most successful production outfit in Philippine cinema, had just launched its own collective of performers, the Regal Babies (three men and three women), and decided to hire Bernal for its Aliw-inspired secondanniversary presentation. Completed in 1979, Manila by Night (which featured three of the Regal Babies' first batch, plus two of Seven Stars' Syete Belyas and a number of other veteran performers) was banned by the military censors for almost a year and disallowed from competing in the Berlin International Film Festival despite having been handpicked by the festival coordinator, Moritz deHadeln. In one sense, Manila by Night (sample scenes in Figure 5) can be seen as largely a critique 
of and partly a corrective to Brocka's more celebrated though conventional neorealist masterwork, Maynila: Sa mga Kuko ng Liwanag (Manila: In the Talons of Light, 1975). It places in context the Brocka film's unconscionable though left-sanctioned anti-Chinese racism and its unexamined sexism and homophobia, and moreover achieves all this and more via an impressive proliferation of main characters -13, by the published screenplay's account (Bernal, "Manila by Night: The Uncensored Screenplay" 23). Bernal himself was unable to replicate the feat represented by Manila by Night, despite his attempts at directing projects with multiple lead performers (see Figure 6 for some later samples). Other local practitioners managed to create fairly successful (in terms of commercial and critical responses) multi-character projects with smaller groups of main characters, notably Marilou Diaz-Abaya with Moral (1982, also produced for Seven Stars) and Brocka himself with Gumapang Ka sa Lusak (Dirty Affair, 1990) - both sharing the same scriptwriter, Ricardo Lee. The format's commercial peak was attained in Maryo J. de los Reyes' Bagets (Young Fellows, 1984), produced by Viva Films, Regal Films' rival, which launched the group using its gay lingo-sourced name in opposition to its rival (i.e., Viva Bagets vis-à-vis Regal Babies).

SPECS

To distinguish the format from the earlier smorgasbord movies (whose narratives tended to resolve by focusing on either an outside adult or a mature couple), Philippine practitioners during the Second Golden Age began using the term "milieu movie" (Lee). The narrative strategy was predicated on two technological developments, the first of which was heralded by foreign film theorists, notably André Bazin, for its ability to resolve the conflict between formalist aesthetics and realism. ${ }^{28}$ The technique, called deep focus, supposedly rendered redundant the need to resort to montage, inasmuch as the visual information accumulated from the practice of cutting from one detail to another could all now be arranged within the same frame and photographed with a large (ideally infinite) depth of field in sharp focus.

The milieu movie, with Nashville as archetype, required a further device, furnished and developed mainly by Robert Altman in the course of building up toward his 1975 masterpiece. Called the Lion's Gate sound system, the innovation simply served to provide an aural equivalent for deep focus, using the even less technologically dependent (i.e., already then readily available) method of recording several separate tracks and mixing them to allow spectators to hear two or more lines of dialog delivered simultaneously. With deep focus and the multi-track sound system instantaneously becoming standard global production features, it becomes possible to see how milieu-movie production could emerge in a Third-World context like the Philippines. ${ }^{29}$ 

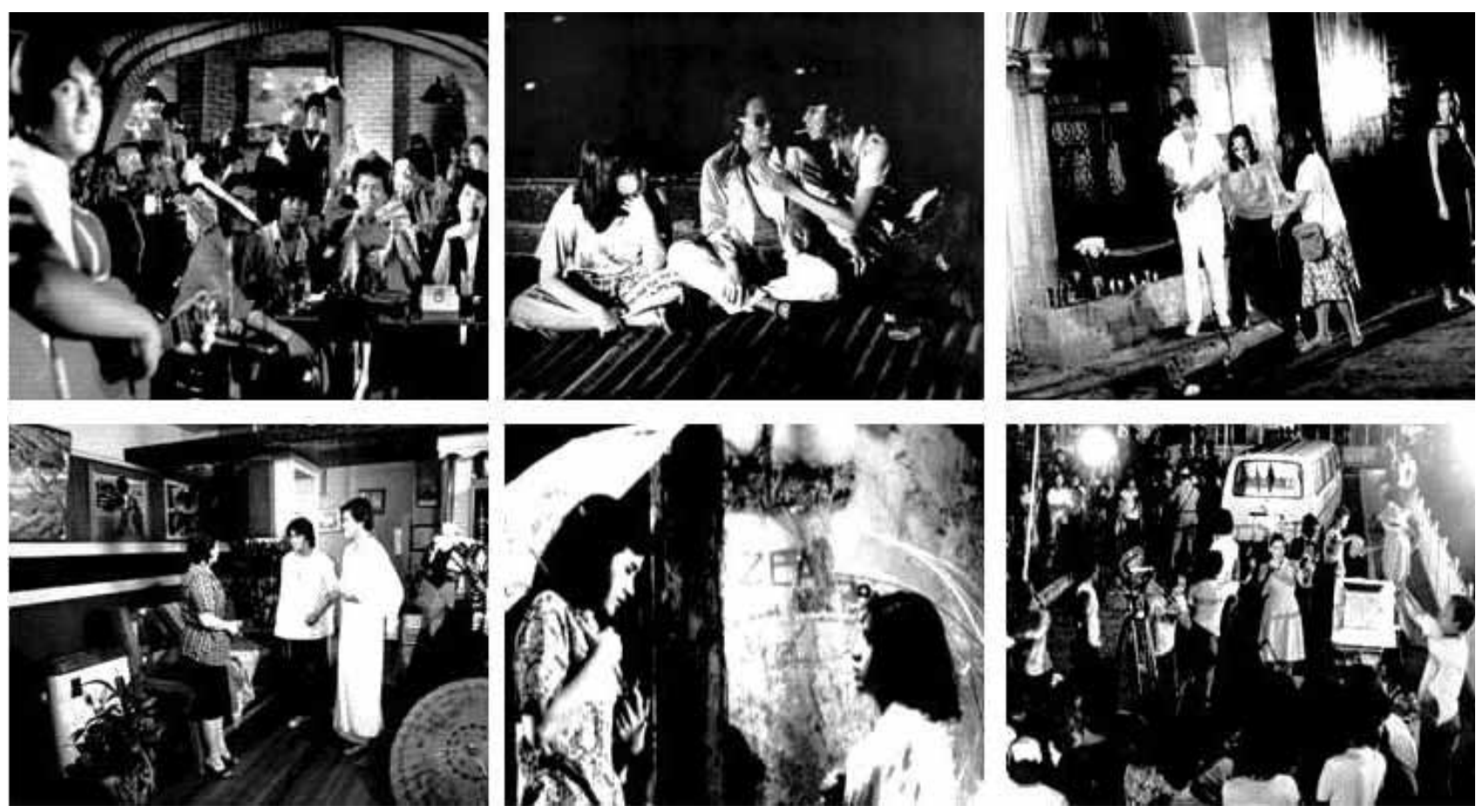

Figure 5

Scenes from Manila by Night, clockwise from top left: gay couturier swoons over folk singer, whom he will eventually successfully seduce; blind masseuse shares pot with her drug-pusher girlfriend and her young girl Friday; masseuse is assisted by gay couturier after praying at a street altar for prostitutes, to seek out a nurse (the common-law wife of the couturier's lover, a taxi driver) who can help her; characters encounter a location shoot outside the hospital where the nurse turns out to be a call girl in disguise; naïve waitress, impregnated by the taxi driver, seeks help from the "nurse," who will be later strangled by an unknown assailant; couturier returns the folk singer to the latter's abusive mother, who also used to be a sex worker. Top middle still courtesy of the Mowelfund Film Institute Audiovisual Archive, used with permission; all other stills courtesy of Bernardo Bernardo, used with permission.

The ultimate contribution of the milieu movie, if one were allowed to make valorizing claims for it, would begin in the area where classical apologists would perceive a weakness in the format. That is, granting a constant commercial running time of about two hours, a larger number of lead characters would result in less actual characters, since less time could be allotted to the development of each one. On the other hand, what one would be left with, in a project (such as Nashville or Manila by Night) with sufficient thematic development, is an agglomeration of types. ${ }^{30}$ Such an absence of "full" dramatic involvement on the part of the spectator with any individual character, intensified by the constant shifting of identification from one character to another, makes it possible for the viewer to configure instead a social formation - in fact, a social character-within the diegesis of the film text. This then is the point in which the milieu movie takes up a certain road not taken by a crucial progressive movement in the history of cinema: that of social realism. Where the 

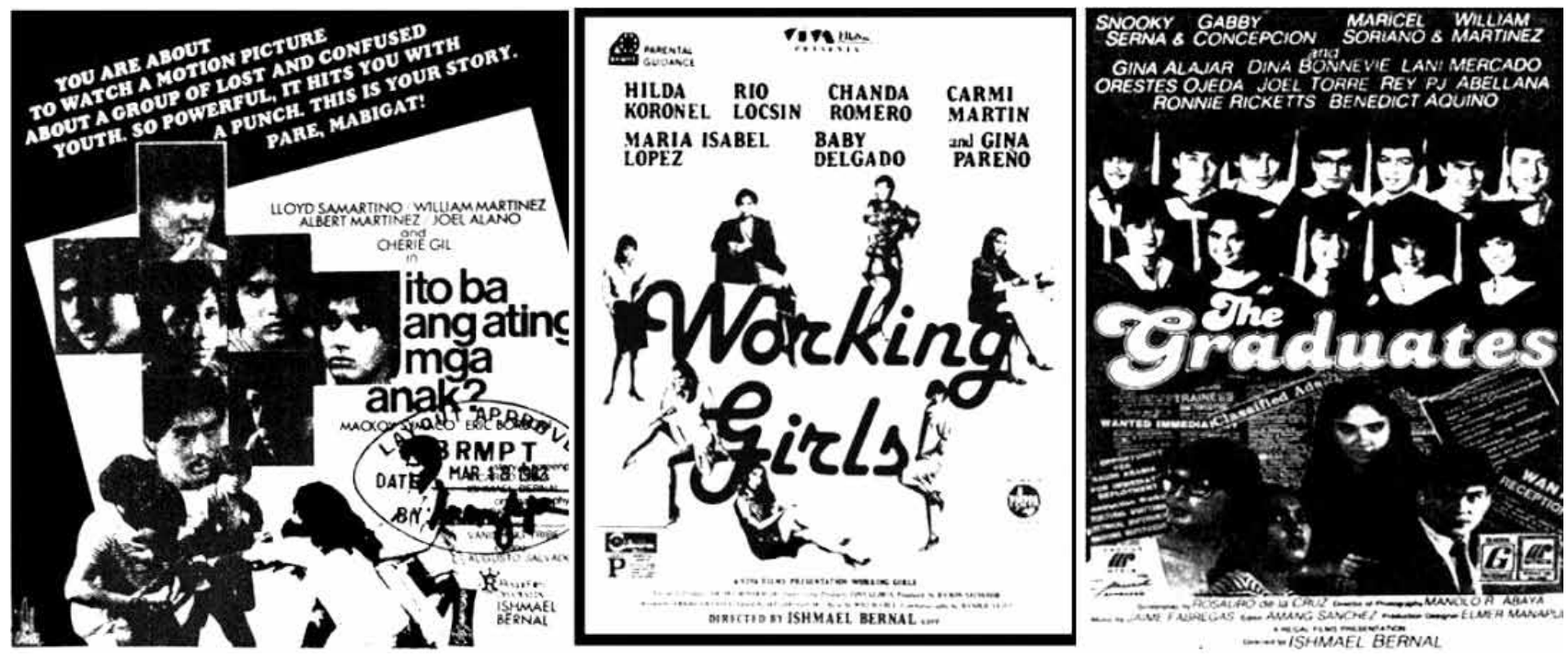

Figure 6

Three of several multi-character movies by Bernal after Manila by Night: Ito Ba ang Ating mga Anak?, on troubled urban youth; Working Girls, on female office workers in the business district; and The Graduates, on young people joining the work force after the period of dictatorship. Newspaper ad layouts posted online by Video 48 weblog, used with permission.

social-realist project was abandoned in classical cinema for some of the same limitations that realism was eventually also critiqued, the milieu movie, in enabling the depiction of interacting social agents, restores a possibility formally unfulfilled by the original social-realist texts.

The obvious consequential query would then center on whether milieu films finally constitute a sample of products that inherently contain progressivity by virtue of their form. I would prefer to defer the answering of this question, since the current article can only go so far in describing the operation of the multi-character film format as a genre, in a highly specific instance, in the Philippines. Perhaps the act itself of valorizing form, of legitimating its status as an engenderer of ideas independent of its originary context, is what we need to caution against.

Much as I would like to avoid resorting to coinages, especially for banausic purposes, I feel the need to distinguish between, on one hand, the accurate depiction of a social reality (with all the problems associable with the assertion of objectivity as the primary goal); and on the other hand, the application of the revolutionary principles of social realism, wherein objectivity, problematically or not, is the first to be discredited and discarded as part of the baggage of bourgeois reformism. One might be able to make the assertion that if "socialness," in foregrounding the delineation of social conditions based on the actuations of the members of (a) society, had been an explicit component of the social realist project, then socialist film practitioners might have been able to 
pioneer in formal innovation the way filmmakers in rival political (i.e., capitalist) spheres had managed to.

A more mundane though also more productive way of ending this consideration of the emergence of a potentially socially inflected formal practice in cinema is to engage in conjecture on the condition of the historical spectator. As our narrative-of-a-narrative unfolded, we had seen an auspicious confluence of factors that inaugurated and nurtured a genuine non-Hollywood multicharacter narrative mode with its own generic underpinnings, including a vernacular terminology. While it may be coincidental for Nashville to have been released during the early years of martial law in the Philippines (the start of the Second Golden Age of local cinema), the fact is that the narrative model it proffered-no singular hero or dual hero/antihero, but rather a multiplicity of main characters - proved to be both irresistible and comprehensible to a Third-World mass audience, despite its consequentially lengthy screening time and complex structure.

If we recall the earlier example of the retablo, which reconfigured the patriarchally singular prescription of Christianity in terms of a less individually focused presentation, we would be able to extrapolate this cultural instance of qualified resistance through the decades of increasing political repression and economic despair. For the viewer during a period of fascist dictatorship, wherein the main source of spectatorial pleasure would be provided by the oppressive capital's amusement industry (Hollywood, standing in for the US and its over-accommodative client state, the Philippines), it would make sense for her to witness figures of glamour, wealth, and power acting out larger-than-life individualized fantasies. But it would also make just as much sense for the same spectator to prefer to witness her own people literally en masse, defying the logic and necessity of individualist agency, performing in separate, sometimes merging or even opposed plotlines wherein only the confluent actuations of the group can propel the entire narrative toward a temporal conclusion. A study that seeks to encompass this speculative, proto-theoretical insight with the reality of, as an example, the multiply-enacted people-power uprising that ended the Marcos dictatorship, would require a description of complex interactive forces, a virtual dispositif that may never be fully disentangled, but that would certainly be easier to understand, and appreciate, from a retrospective contemplation of the Pinoy multi-character movie. 


\section{NOTES}

The terms used by Farber in the course of his article were as follows, in chronological order: "labyrinthine narrative"; "complex cinematic mosaic with multiple story lines" (after Robert Altman); "movies with interlocking plots"; "movies with a multiplicity of plots"; "multi-narrative approach"; "interlacing multiple plot lines"; "profusion of plots"; "multiple narrative format"; and "movies with multiple story lines" ("A Half-Dozen Ways"). As if to play up the recency of the trend, the article mentions "the influence of Robert Altman" but specifies only "acclaimed films from the last decade ... [that] have made this fragmented style familiar, as have television shows." An extensive attempt at genealogizing Robert Ebert's use of the term "hyperlink movie" appears in the Syriana blog at the Kottke.org website. A more recent New York Times article reviewing a recent release, Ray Lawrence's Jindabyne, closes with a reference to "the kind of multi-stranded narrative that has become ... the dominant genre of international prestige filmmaking" (Scott). The most technically accurate descriptor would be the title of María del Mar Azcona's recent volume, The Multi-Protagonist Film. The book also identifies this type of film as a genre, but strictly as a retrospective response: "what started as a narrative structure gradually acquired the status of a genre," defending the categorization by asserting "the growing visibility of the term as a generic label in critical discourse" (1) - a highly contestible declaration in Western critical practice.

The Syriana DVD website features a quote from Stephen Gaghan where he iterates that "We are living in complex, difficult times and I wanted Syriana to reflect this complexity in a visceral way, to embrace it narratively.... The hope was that by not wrapping everything up, the film will get under your skin in a different way and stay with you longer." Gaghan designates his temporal motive when he states that the approach "seemed like the most honest reflection of this post-9/11 world we all find ourselves in."

The most prominent US iconographic personalities in the representations of Philippine-American military conflicts would be Brigadier General Jacob "Howling" Smith, a veteran of the anti-Native American campaigns; and Colonel Edward Lansdale, who as an operative of the Central Intelligence Agency would claim to have spearheaded the use of horrendous psychological warfare tactics in the Vietnam War, employing methods first applied against Philippine Communist insurgents. For a detailed accounting of the story of Smith based on official documents, see Joseph L. Schott's The Ordeal of Samar; on Lansdale, see his autobiographical In the Midst of Wars 13-82 passim (66-68 details how he and then-Defense Secretary, later President, Ramon Magsaysay, planned their antiinsurgency campaigns); also Smith's Portrait of a Cold Warrior 103-05. See also critiques of Schott's generally well-meaning account in Balangiga.

The US Supreme Court decision dated 2 Dec. 1901 regarding tariff law concerning the Philippines referred to the war as an "insurrection," while the US Philippine Commission passed an act in November 1902 that defined resistance to the US as a criminal act of banditry punishable under civil law. Copies of these documents are posted online, respectively: United States Supreme Court, The Diamond Rings; and United States Philippine Commission, “The Bandolerismo Statute." 
Reynaldo C. Ileto has remarked that "much scholarly writing on the Philippines bears the stamp of a certain familiarity with which the country's traditions and patterns of development have been treated. In contrast to those parts of Southeast Asia that have been transformed by the 'great traditions' ... and which, as a result, have had the aura of the exotic and impenetrable about them, the Philippines has appeared transparent and knowable, a 'natural' consequence of the experience of some four hundred years of Spanish and American colonialism" (29). The observation applies to instances when relevant scholarship occurs at all. David D. Newsom's version of his extensive tours of duty (including a stint as US ambassador to the Philippines during the Marcos era) includes the now-standard and expected problematizing of US involvement in the Vietnam conflict and the Gulf War, but regards Philippine-US relations as having stabilized with the end of the Fil-American War (59-60), eliding, among several other possible first-person accounts, the US's initial support for and eventual abandonment of Marcos's fascist rule. Hau upholds a realist position in accounting for matter and idea in the world, as opposed to constructivism, which holds that "we cannot in principle know anything about the mindindependent world (let alone the ways in which this world exercises constraints on us and our knowledge)" (22).

$7 \quad$ For an effective refutation of Jameson's premises, see Felicidad C. Lim's "Perfumed Nightmare and the Perils of Jameson's ‘New Political Culture."” In "Philippine Cinema," Clodualdo A. del Mundo collated data from three different sources in order to construct his tabulations, but encountered a gap (recently filled by a graduate thesis at the University of the Philippines) during the sixties. The available data list 93 productions as of 1960 and 225 in 1970, so it would be virtually certain that the hundreds figure first occurred during the intervening years. Standard Philippine sources indicate as well that the highest annual output was 1970's 225, with 1971 also in the two hundreds, with the trend having started during the late sixties. The tapering off to the 150s during the early martial law years represented the average annual production during the years since then, with a decline to 1950s levels after the turn of the millennium. Interior Secretary Dean C. Worcester proposed in 1909 the filming of Philippine folkways and culture to be preserved for whatever future studies it may serve "before Western influences irretrievably corrupted them" (qtd. in De Pedro 26). Typical of early proponents of film use and language, he implemented his recommendation in a number of book and film projects. The American Film Institute Catalog of Feature Films lists his 1914 "documentary" Native Life in the Philippines, "divided into two six-reel parts, the first called The Head Hunters, the second variously called From Savages to Civilization and From Savages to Citizens in different ads." The catalog's summary of Worcester's presumably uncorrupted film-text is as follows:

A member of the Bontoc Igorot tribe ... [kills] a sentry from a neighboring tribe and [brings] his head back in order to earn the right to marry a woman.... The resulting marriage ceremony, described as a "dog feast" in one review, and the return of a head to the tribe of the victim, as ordered by the government, are also shown. Other scenes depicted ... include ... a documentation of the societal changes wrought by American control of the Philippines, including vocational and athletic training, education and the introduction of Christian marriage. 

paid least attention and has been least successful in treating" (230). He attributes this state of affairs to two causes: one, on structuralists' laying stress "on the interpersonal and conventional systems which traverse the individual, which make him a space in which forces and events meet rather than an individuated essence"; and another, to the Foucaldian "historical distinction" of regarding man as "simply a fold in our knowledge who will disappear in his present form as soon as the configuration of knowledge changes" (230-31). He then summarizes the various models for approaching character advanced, in chronological order, by Vladimir Propp, A. J. Greimas, Tzvetan Todorov, and Northrop Frye (Culler 232-36)-each one purportedly critiquing the last for arriving at a typology that applies to certain literary instances but proves incapable of containing others. For a summary of the shifts in Barthes's disquisitions on the nature and status of characters in narrative theory, see Seymour Chatman 114-16. Chatman's remark that a "viable theory of character should preserve openness and treat characters as autonomous beings, not as mere plot functions" by reconstructing character through the audience (119) appears more reliant on Barthes's original position. He also broaches a diagrammatic system of analyzing character through a "paradigm of traits" firmly rooted in setting (126-45) that may prove useful in tracing and determining the existence of the multiple-character format. The critique of studies of national cinemas as proceeding from the desire to maintain coherence and unity, and to posit a resistance to Hollywood domination, had been made by Andrew Higson (37). His admonition "to take into account the film culture as a whole, and the over-all institution of cinema" (44) has been paralleled in a call I had made for Philippine cinema to consider "the role in both local production and local and foreign exhibition played by an entity that, for the sake of convenience, may still be called Hollywood, and represented in the Philippines by a highly influential lobby of foreign-film distributors" (David, Fields of Vision 35). Culture noted the relative proliferation of multiple-character films in the seventies and attributed the phenomenon to the maturation of baby boomers (519) - an essentialist inference that I am not in a position to contest or verify. Wave," opens with the observation that "A new style of film emerged in the 1990s which violates the usual construction of a screenplay's formula. These are films with multiple plots in which there is no central lead in the traditional sense" (Egan). While in Wood's study he could note that the multiple character format is typical of disaster films and teen pics, a rupture can be seen in the manner in which Nashville has been classified here and elsewhere: whether as a disaster (and disastrous) film, in Wood's view, or as a comedy or a musical, in separate anthologies by the National Society of Film Critics - cf., respectively, Stuart Byron, ed., The National Society of Film Critics on Movie Comedy; and "Genre Classics" in Richard T. Jameson, ed., They Went Thataway 347-54. 
Earlier discussions of the discursive nature of film would include Pier Paolo Pasolini, who concluded that cinema's political potential would be directly metaphorical in nature (549-50); and Christian Metz, who modified this insight by asserting that filmic metaphors are actually metonymic, each diegetic element symbolizing the whole of its context and playing on forms of contiguity within the same figure (568-78). As a historiographic sketch of Philippine film-history texts, the article provides a critical survey of histories of Philippine cinema up to the mid-nineties. The author acknowledges the precedence of a similar exercise by Patrick D. Flores, published in his book Sites of Review.

The absurdity of approaching Philippine film history primarily in terms of its "Golden Ages" lies not so much in the validity of whether such periods existed or what their exact temporalities were, but rather in the danger of valorizing the socioeconomic conditions that accompanied the periods and failing to see the output as a result of a clash of severe and occasionally violent contradictions. A more determinedly minor absurdity has also recently surfaced, in that the pre-World War II period, with its virtually unavailable celluloid samples, is being claimed to have yielded its own Golden Age-a dubious process ironically sanctioned in the Philippine government's semi-official account. Articles that pioneered in the Golden Ages claim are: Jessie B. Garcia, "The Golden Decade of Filipino Movies," celebrating the 1950s studio system; Joel David, "A Second Golden Age (An Informal History)" in The National Pastime, tackling the martial-law period of roughly the 1970s to mid-1980s; and Nestor U. Torre, "Classics of the Filipino Film," recapitulating the earlier periods and adding a preceding one, comprising the 1930s and 1940s.

Within three comprehensive anthological sources alone, the consensus among the three authorsBienvenido Lumbera, Nicanor G. Tiongson, and Petronilo Bn. Daroy-is, for better or worse, extensive, insistent, and learned. In Rafael Ma. Guerrero, ed., Readings in Philippine Cinema, cf. Lumbera, "Problems in Philippine Film History"; Tiongson, "From Stage to Screen: Philippine Dramatic Traditions and the Filipino Film"; and Daroy, "Social Significance and the Filipino Cinema." In Tiongson, ed., The Urian Anthology, cf. Lumbera, "Kasaysayan at Tunguhin ng Pelikulang Pilipino" [The History and Prospects of the Filipino Film] and "Approaches to the Filipino Film"; Tiongson, "Four Values in Filipino Drama and Film"; and Daroy, "Main Currents in the Filipino Cinema." In Tiongson, ed., Philippine Film, cf. Lumbera, "Philippine Film"; and Lumbera, Marra PL Lanot, Rosalie Matilac, Lena S. Pareja, and Tiongson, "Sources and Influences."

One of the earlier attempts to apply a cultural studies approach to Philippine film samples was that of Emmanuel A. Reyes in Notes on Philippine Cinema. While avoiding the tactic, typical of academebased commentators but much reviled (and understandably so) by local film artists, of pinpointing a seemingly apposite foreign-sourced theory then setting a popular local release against it, Reyes proceeds by recounting David Bordwell's concept of classical Hollywood narrative cinema, listing four of its salient elements and contrasting these with their counterparts in Philippine commercial practice. Reyes's refusal to pass judgment on the results of the comparison is laudable, but a closer inspection of the respective clash of values between what the colonizing center and the postcolonial margin respectively champion still winds up undermining the native cultural product (but not the 
foreign-sourced theory) in the process: scenes (in the Philippine context) rather than Hollywood's plots, overt rather than subtle representations, circumlocutory rather than economical dialog, and the centrality of the star rather than her performance (15-25). In fact, perhaps the most disturbing conclusion that Del Mundo makes is that the films in his study, by attempting to be true to impossibly opposed production modes (e.g., musical numbers about trivial concerns in English betray native values while settling for poor production values and thus appearing inferior to Hollywood), succeed in neither and suffer in comparison to both (Del Mundo, Native Resistance 121-23). An explication of the origins and usefulness of ethnomethodology and conversation analyses, among other approaches, can be found in the introductory chapter of Toby Miller and Alec McHoul's Popular Culture and Everyday Life (1-27). Referring to the second type of film genre, Thomas Schatz relates that in examining "these popular narratives whose plots, characters, and themes are refined through usage in a mass medium, we are considering a form of artistic expression which involves the audience more directly than any traditional art form had ever done before" (11); later he distinguishes generic categories in literature as "representing the efforts of critics of historians to organize the subject matter ... in terms that may be irrelevant to those who produce and consume them" (15, emphasis mine). On the other hand, the multiple-character format departs from a reformulation of social realism in cinema in the question of the function of objectivity. As I had earlier clarified, "Granting the twin assumptions of each character having separate but equal importance and engendering competing imperatives of spectatorial identification," one lead performer would be "traditional" while two would be "possibly dialectical but not literally 'social"" (David, Wages of Cinema 18). This narrative mode of upholding a singular character within a large social milieu arguably became the defining structure for social realist cinema, notably in the output of Italian neorealism. Philippine film samples with such structures include Lino Brocka's small-town opuses Tinimbang Ka Nguni't Kulang (You Were Weighed But Found Wanting, 1974) and Miguelito: Ang Batang Rebelde (Miguelito: The Rebel Child, 1985) and political dramas Maynila: Sa mga Kuko ng Liwanag (1975) and Orapronobis (Fight for Us, 1989); Mike de Leon's anti-fascist critiques Kisapmata (In the Wink of an Eye, 1981) and Batch '81 (1982); Eddie Romero's period discourses Ganito Kami Noon ... Paano Kayo Ngayon? (As We Were, 1976) and Aguila (1980); and any number of social epics by action stars Joseph Estrada and Fernando Poe, Jr. Closer to the Malvarosa model of having a woman as social hero would be Celso Ad. Castillo's Burlesk Queen (1977), Brocka's Gumapang Ka sa Lusak (Dirty Affair, 1990), and Bernal's Himala (Miracle, 1982).

$27 \quad$ Lino Brocka's entry, titled Lunes, Martes, Miyerkules, Huwebes, Biyernes, Sabado, Linggo (1976), purported to feature the female performers of a night club in the former US naval base district of Olongapo, with one woman representing each of the seven days of the week - hence the title. Nevertheless the narrative is actually determined by the search of a man for his mother, who turns out to be one of the club's hasbeen entertainers. Even more revealing is Brocka's subsequent contention, when confronted with the 
question of why he tended to portray defeated heroes, that "the individual's awareness must first be raised before a group can act intelligently.... Mob mentality does not imply the masses' undoing but serves as the foil to an individual's awakening" (Lanot n.p.). Bazin's critique of montage and valorization of deep focus appear respectively in two articles in What Is Cinema? - "The Virtues and Limitations of Montage" (41-52) and "The Evolution of the Language of Cinema" (23-40). David Bordwell in On the History of Film Style describes the opposition between realism and formalism in film as the standard version of stylistic history (27-34), and pays tribute to what he described as the best mind ever to reflect on cinema (6) in his chapter "Against the Seventh Art: André Bazin and the Dialectical Program" (46-82). A technological valorization of the audiovisual strategies in multi-character film (cf. David, Wages of Cinema 14-25) could center on the utilization of deep-focus cinematography, which enables actors to be positioned within the same shot; more important is the innovation in Nashville of an aural equivalent of deep-focus, pursued independently in a later article by Rick Altman titled "24-Track Narrative?" The other sources cited include Barbara Klinger, "'Cinema/Ideology/ Criticism' Revisited"; Michele Barrett, "The Place of Aesthetics in Marxist Criticism"; and Fredric Jameson, "Cognitive Mapping." In “Can People Be (Re)Presented in Fiction?" Darko Suvin enumerates characters, types, and actants as the three kinds of agential levels $(679,686)$. Characters interrelate dialectically with the historical concepts of types and developed along with capitalist ideals of property, money economy, etc.; they once broke through hierarchies and dogmas but do not suffice anymore in depicting contemporary corporative individualities, and in effect they tend to engender new monopolistic and stereotypical production (688). Stanley Cavell in "Types" goes further by upholding the use of types in cinema on the premise that the medium creates not (real) individuals, but individualities (297-99). 


\section{WORKS CITED}

Altman, Rick. "24-Track Narrative? Robert Altman's Nashville." Cinémas: Revue d'études cinématographiques/ Journal of Film Studies 1.3. 1. Apr. $2007<$ http://www.revue-cinemas.umontreal.ca/vol001no03/08altman.htm>.

Azcona, María del Mar. The Multi-Protagonist Film: New Approaches to Film Genre. West Sussex: WileyBlackwell, 2010.

Balangiga: Official Web Home of the Balangiga Research Group. 1 Apr. 2007 <http://balangiga.bobcouttie.com>.

Barrett, Michele. "The Place of Aesthetics in Marxist Criticism." Marxism and the Interpretation of Culture. Eds. Cary Nelson and Lawrence Grossberg. Urbana: U of Illinois P, 1988. 697-713.

Barthes, Roland. "Introduction to the Structural Analysis of Narratives." Image, Music, Text. Trans. Stephen Heath. New York: Noonday, 1977. 79-124.

-. S/Z. Trans. Richard Miller. New York: Noonday, 1974.

Bazin, André. What Is Cinema? Vol. 1. Ed. and Trans. Hugh Gray. Berkeley: U of California P, 1967. 2 vols.

Bernal, Ishmael. "Manila by Night: The Uncensored Screenplay." The Review 4.3 (1981): 23-41.

Bordwell, David. On the History of Film Style. Cambridge, Mass.: Harvard UP, 1997.

Byron, Stuart, ed. The National Society of Film Critics on Movie Comedy. New York: Grossman, 1977.

Cavell, Stanley. "Types; Cycles as Genres." Film Theory and Criticism: Introductory Readings. $4^{\text {th }}$ ed. Eds. Gerald

Mast, Marshall Cohen, and Leo Braudy. New York: Oxford UP, 1992. 294-99.

Chatman, Seymour. Story and Discourse: Narrative Structure in Fiction and Film. Ithaca: Cornell UP, 1978.

Christie, Ian. "Soviet Cinema: A Heritage and its History." The Film Factory: Russian and Soviet Cinema in

Documents. Trans. Richard Taylor. Eds. Richard Taylor and Ian Christie. Cambridge: Harvard UP, 1988. 1-17.

Culler, Jonathan. Structuralist Poetics: Structuralism, Linguistics and the Study of Literature. Ithaca: Cornell UP, 1975.

Daroy, Petronilo Bn. “Main Currents in the Filipino Cinema." Urian Anthology 1970-79. Ed. Nicanor G.

Tiongson. Manila: M.L. Morato, 1983. 48-61.

-. "Social Significance and the Filipino Cinema." Readings in Philippine Cinema. Ed. Rafael Ma. Guerrero.

Manila: Experimental Cinema of the Philippines, 1983. 95-108.

David, Joel. “The Fantasy World of Rey de la Cruz.” New Day 6 Oct. 1986: 12-14.

-. Fields of Vision: Critical Applications in Recent Philippine Cinema. Quezon City: Ateneo de Manila UP, 1995.

-. The National Pastime: Contemporary Philippine Cinema. Metro Manila: Anvil, 1990.

-. Wages of Cinema: Film in Philippine Perspective. Quezon City: U of the Philippines P, 1998.

De Pedro, Ernie. “Overview of Philippine Cinema." Filipino Film Review 1.4 (1983): 26-27.

Del Mundo, Clodualdo A. Native Resistance: Philippine Cinema and Colonialism, 1898-1941. Manila: De La Salle UP, 1998.

-. "Philippine Cinema: An Historical Overview." Asian Cinema 10.2 (1999): 29-66.

Deleuze, Gilles. Cinema 1: The Movement-Image. 1983. Trans. Hugh Tomlinson and Barbara Habberjam.

Minneapolis: U of Minnesota P, 1986. 
-. Cinema 2: The Time-Image. 1985. Trans. Hugh Tomlinson and Robert Galeta. Minneapolis: U of Minnesota $\mathrm{P}, 1989$.

Egan, John. "The '90s New Wave." The Praxis Newsletter. 1 Apr. 2007 <http://www.praxisfilm.com/en/ libraryresources/praxisnewsletters/fall2000newsletter/default.aspx>.

Farber, Stephen. "A Half-Dozen Ways to Watch the Same Movie." New York Times 13 Nov. 2005. 18 Nov. 2005 $<$ http://www.nytimes.com/pages/movies/index.html>.

-, and Marc Green. Outrageous Conduct: Art, Ego, and the Twilight Zone Case. New York: Arbor House/ Morrow, 1988.

Flores, Patrick D. Sites of Review: Critical Practice in Media. San Pablo: Oraciones, 1996.

Garcia, Jessie B. “The Golden Decade of Filipino Movies.” Guerrero 39-54.

Guillermo, Alice. “Understanding Film.” Images of Change. Quezon City: Kalikasan, 1988.

Hassler-Forest, Dan. "Multiple Narrative in Contemporary Cinema." Dan's Movie Madness Pages. 1 Apr. 2007 $<$ http://www.euronet.nl/users/mcbeijer/dan/mns/mns.html>.

Hau, Caroline S. “On Representing Others: Intellectuals, Pedagogy, and the Uses of Error.” Journal of English Studies and Comparative Literature 1.2 (1998): 3-36.

Higson, Andrew. “The Concept of National Cinema." Screen 30.4 (1989): 36-46.

Ileto, Reynaldo C. Filipinos and their Revolution: Event, Discourse, and Historiography. Quezon City: Ateneo de Manila UP, 1998.

Jameson, Fredric. "Cognitive Mapping." Marxism and the Interpretation of Culture. Eds. Cary Nelson and Lawrence Grossberg. Urbana: U of Illinois P, 1988. 347-57 (panel discussion 358-60).

-. The Geopolitical Aesthetic: Cinema and Space in the World System. Bloomington: Indiana UP, 1992.

Jameson, Richard T., ed. "Genre Classics." They Went Thataway: Redefining Film Genres - A National Society of Film Critics Video Guide. San Francisco: Mercury House, 1994. 347-54.

Javellana, Rene B. "Retablo." Philippine Architecture. CCP Encyclopedia of Philippine Art. Vol. 3 of 9 vols. Ed. Nicanor G. Tiongson. Manila: Cultural Center of the Philippines, 1994. 156-57.

Klinger, Barbara. "“Cinema/Ideology/ Criticism' Revisited: The Progressive Genre.” Film Genre Reader. Ed. Barry Keith Grant. Austin: U of Texas P, 1986. 74-90.

Knee, Adam. "The Compound Genre Film: Billy the Kid Versus Dracula Meets The Harvey Girls." Intertextuality in Literature and Film: Selected Papers from the Thirteenth Annual Florida State University Conference on Literature and Film. Eds. Elaine D. Cancalon and Antoine Spacagna. Gainesville: UP of Florida, 1994. 141-56.

Lanot, Marra PL. “Lino Brocka: The Boy from San Jose Goes to Cannes.” Pelikula, Atbp. (18 Feb. 2009): n.p. Rpt. from The Trouble with Nick and Other Profiles (Quezon City: University of the Philippines Press, 1999). 29 Jun. 2011 <http://pelikulaatbp.blogspot.com/2009/01/lino-brocka-boy-from-san-jose-goes-to.html> .

Lansdale, Edward Geary. In the Midst of Wars: An American's Mission to Southeast Asia. 1972. New York: Harper and Row, 1991.

Lee, Ricardo. Personal interview. Quezon City, 10 Aug. 2008.

Lim, Felicidad C. "Perfumed Nightmare and the Perils of Jameson's 'New Political Culture."' Philippine Critical Forum 1.1 (1995): 24-37. 
Lumbera, Bienvenido. "Kasaysayan at Tunguhin ng Pelikulang Pilipino" [The History and Prospects of the Filipino Film]. Urian Anthology 1970-79. Ed. Nicanor G. Tiongson. Manila: M.L. Morato, 1983. 22-47. -. "Philippine Film." Philippine Film. CCP Encyclopedia of Philippine Art. Vol. 8. Ed. Nicanor G. Tiongson. Manila: Cultural Center of the Philippines, 1994.

-. "Problems in Philippine Film History." Readings in Philippine Cinema. Ed. Rafael Ma. Guerrero. Manila: Experimental Cinema of the Philippines, 1983. 67-79.

-, Marra PL Lanot, Rosalie Matilac, Lena S. Pareja, and Nicanor G. Tiongson. "Sources and Influences." Philippine Film. CCP Encyclopedia of Philippine Art. Vol. 8. Ed. Nicanor G. Tiongson. Manila: Cultural Center of the Philippines, 1994.

Metz, Christian. "Current Problems of Film Theory: Mitry's L'esthetique et psychologie du cinema, vol. II." Trans. Diana Matias. Movies and Methods: An Anthology. Vol. 1. Ed. Bill Nichols. Los Angeles: U of California P, 1976. 568-78.

Miller, Toby, and Alec McHoul. Popular Culture and Everyday Life. London: Sage, 1998.

Newsom, David D. The Imperial Mantle: The United States, Decolonization, and the Third World. Bloomington: Indiana UP, 2001.

Pasolini, Pier Paolo. “The Cinema of Poetry.” Trans. Marianne de Vettimo and Jacques Bontemps. Movies and Methods: An Anthology. Vol. 1. Ed. Bill Nichols. Los Angeles: U of California P, 1976. 542-58.

Reyes, Emmanuel A. Notes on Philippine Cinema. Manila: De La Salle UP, 1989.

Ryan, Michael, and Douglas Kellner. Camera Politica: The Politics and Ideology of Contemporary Hollywood Film.

Bloomington: Indiana UP, 1988.

Sarton, May. Mrs. Stevens Hears the Mermaids Singing. New York: Norton, 1965.

Schatz, Thomas. Hollywood Genres: Formulas, Filmmaking, and the Studio System. New York: McGraw-Hill, 1981.

Schott, Joseph L. The Ordeal of Samar. 1964. Filipiniana Reprint Series 19. Manila: Solar, 1987.

Scott, A. O. "Murky Emotions Floating to the Surface." Rev. of Jindabyne, by Ray Lawrence. New York Times 27 Apr. 2007. 29 Apr. 2007 <http://www.nytimes.com/pages/movies/index.html>.

Smith, Joseph B. Portrait of a Cold Warrior. New York: Putnam's, 1976.

Stern, Jane, and Michael Stern. "thirtysomething." Encyclopedia of Pop Culture: An A to Z of Who's Who and What's What, From Aerobics and Bubble Gum to Valley of the Dolls and Moon Unit Zappa. New York: Harper, 1992.

Suvin, Darko. "Can People Be (Re)Presented in Fiction? Toward a Theory of Narrative Agents and a Materialist Critique Beyond Technocracy or Reductionism." Marxism and the Interpretation of Culture. Eds. Nelson, Cary, and Lawrence Grossberg. Urbana: U of Illinois P, 1988. 663-96.

Syriana. DVD website. 13 May 2007 <http://syrianamovie.warnerbros.com/about.html>.

"Syriana." Kottke.org blog entry. 10 Feb. 2006. 13 May $2007<$ http://www.kottke.org/06/02/syriana>.

Tiongson, Nicanor G. "From Stage to Screen: Philippine Dramatic Traditions and the Filipino Film." Readings in Philippine Cinema. Ed. Rafael Ma. Guerrero. Manila: Experimental Cinema of the Philippines, 1983. 83-94.

Torre, Nestor U. “Classics of the Filipino Film." Philippine Film. CCP Encyclopedia of Philippine Art. Vol. 8. Ed. Nicanor G. Tiongson. Manila: Cultural Center of the Philippines, 1994. 
Tudor, Andrew. "Genre and Critical Methodology." Movies and Methods: An Anthology. Vol. 1. Ed. Bill Nichols. Los Angeles: U of California P, 1976. 111-17.

United States Philippine Commission. "The Bandolerismo Statute." Fourth Annual Report of the Philippine Commission, 1903. Washington: Government Printing Office, 1904. 31 Mar. $2007<\mathrm{http} / / / w w w$. boondocksnet.com/centennial/sctexts/bandolerismo_statute.html>.

United States Supreme Court. The Diamond Rings. 183 US 176 (1901). 31 Mar. 2007 <http://supreme.justia.com/ us/183/176/case.html>.

Wood, Robin. Hollywood from Vietnam to Reagan. New York: Columbia UP, 1986.

\section{FILMOGRAPHY}

Aguila. Dir. and scriptwriter Eddie Romero. Perf. Fernando Poe, Jr., Amalia Fuentes, Christopher de Leon, Elizabeth Oropesa, Jay Ilagan, Charo Santos, Chanda Romero, Daria Ramirez, Eddie Garcia, Celia Rodriguez, Orestes Ojeda, Susan Valdez, Johnny Delgado, Sandy Andolong, Conrad Poe, Ricky Sandico, Joonee Gamboa, Behn Cervantes, and Roderick Paulate. Bancom Audiovision, 1980.

Aliw [Pleasure]. Dir. Ishmael Bernal. Scriptwriter Cecille Lardizabal [also Ishmael Bernal and Franklin Cabaluna]. Perf. Amy Austria, Lorna Tolentino, Suzette Ranillo, Cesar Topacio, Butz Aquino, Rustica Carpio, George Estregan, Dick Israel, Jojo Santiago, Juan Rodrigo, Menggie Cobarrubias, Laura Danao, Ruthie Roces, and Ramon Recto. Seven Stars, 1979.

American Graffiti. Dir. George Lucas. Scriptwriters Gloria Katz, Willard Huyck, and George Lucas. Perf. Richard Dreyfuss, Candy Clark, Ron Howard, Paul Le Mat, Cindy Williams, Charles Martin Smith, Harrison Ford, Mackenzie Phillips, Wolfman Jack, Bo Hopkins, Manuel Padilla, Jr., and Beau Gentry. Universal, 1973.

Babel. Dir. Alejandro González Iñárritu. Scriptwriter Guillermo Arriaga. Perf. Brad Pitt, Cate Blanchett, Mohamed Akhzam, Peter Wright, Harriet Walter, Trevor Martin, Matyelok Gibbs, Georges Bousquet, Claudine Acs, Adriana Barraza, Elle Fanning, Natham Gamble, Gael García Bernal, and Rinko Kikuchi. Paramount, 2006.

Bagets [Young Fellows]. Dir. Maryo J. de los Reyes. Scriptwriter Jake Tordesillas. Perf. William Martinez, Aga Muhlach, Herbert Bautista, JC Bonnin, Raymond Lauchengco, Jobelle Salvador, Yayo Aguila, and Eula Valdez. Viva, 1984.

Batch '81. Dir. Mike de Leon. Scriptwriters Clodualdo del Mundo, Jr., Racquel Villavicencio, and Mike de Leon. Perf. Mark Gil, Sandy Andolong, Ward Luarca, Noel Trinidad, Armida Siguion-Reyna, Chanda Romero Chito Ponce-Enrile, Ricky Sandico, Jimmy Javier, Rod Leido, Bing Pimentel, Dang Cecilio, Mike Arvisu, Vic Lima, Edwin Reyes, Nanette Inventor, and Joe Jardi. MVP Pictures, 1982.

Burlesk Queen. Dir. Celso Ad. Castillo. Scriptwriter Mauro Gia. Samonte. Perf. Vilma Santos, Leopoldo Salcedo, Rolly Quizon, Rosemarie Gil, Roldan Aquino, Joonee Gamboa, Chito Ponce-Enrile, Dexter Doria, Rio Locsin, Yolanda Luna, Estrella Kuenzler. Ian, 1977.

Crash. Dir. Paul Haggis. Scriptwriters Bobby Moresco and Paul Haggis. Perf. Sandra Bullock, Don Cheadle, Art Chudabala, Sean Cory, Tony Danza, Keith David, Loretta Devine, Matt Dillon, Michael Peña, 
Jennifer Esposito, Eddie J. Fernandez, Nona Gaye, William Fichtner, Ludacris, Terrence Howard, Thandie Newton, Ryan Phillippe, and Larenz Tate. Lions Gate, 2004.

Dalawang Pugad, Isang Ibon [Two Nests, One Bird]. Dir. and scriptwriter Ishmael Bernal. Perf. Vilma Santos,

Romeo Vasquez, Mat Ranillo III, Anita Linda, Fred Montilla, and Mary Walter. Lea, 1977.

Ganito Kami Noon ... Paano Kayo Ngayon? [As We Were]. Dir. Eddie Romero. Scriptwriters Eddie Romero and Roy Iglesias. Perf. Christopher de Leon, Gloria Diaz, Eddie Garcia, Dranreb, Leopoldo Salcedo,

Rosemarie Gil, E. R. Rocha, Tsing Tong Tsai, Johnny Vicar, and Jaime Fabregas. Hemisphere, 1976.

Gumapang Ka sa Lusak [Dirty Affair; literally, Crawl through the Muck]. Dir. Lino Brocka. Scriptwriter Ricardo

Lee. Perf. Dina Bonnevie, Eddie Garcia, Charo Santos-Concio, Bembol Roco, Christopher de Leon,

Allan Paule, Anita Linda, Francis Magalona, Perla Bautista, William Lorenzo, Timothy diwa, Rey

Ventura, and Tess Dumpit. Viva, 1990.

Himala [Miracle]. Dir. Ishmael Bernal. Scriptwriter Ricardo Lee. Perf. Nora Aunor, Gigi Dueñas, Veronica

Palileo, Spanky Manikan, Vangie Labalan, Laura Centeno, Amable Quiambao, Ben Almeda, Cris

Daluz, Aura Mijares, Joel Lamangan, Ray Ventura, Pen Medina, Tony Angeles, Joe Gruta, and Lem

Garcellano. Experimental Cinema of the Philippines, 1982.

Ikaw Ay Akin [You Are Mine]. Dir. Ishmael Bernal. Scriptwriter Jose N. Carreon. Perf. Christopher de Leon,

Nora Aunor, Vilma Santos, Ernie Zarate, Nick Romano, Ellen Esguerra, Zandro Zamora, Odette

Khan, Ven Medina, and Angel Confiado. Tagalog Ilang-Ilang, 1978.

Jindabyne. Dir. Ray Lawrence. Scriptwriter Beatrix Christian. Perf. Laura Linney, Gabriel Byrne, Deborra-lee

Furness, John Howard, Leah Purcell, Stelios Yiakmis, Alice Garner, Simon Stone, Sean Rees-Wemyss, and Betty Lucas. Sony, 2006.

Kisapmata [In the Wink of an Eye]. Dir. Mike de Leon. Scriptwriters Clodualdo del Mundo, Jr., Racquel

Villavicencio, and Mike de Leon. Perf. Vic Silayan, Charo Santos, Charito Solis, Jay Ilagan, Ruben

Rustia, Aida Carmona, Juan Rodrigo, Dindo Angeles, and Edwin O'Hara. Bancom Audiovision, 1981.

The Long Goodbye. Dir. Robert Altman. Scriptwriter Leigh Brackett. Perf. Elliott Gould, Nina Van Pallandt,

Sterling Hayden, Mark Rydell, Henry Gibson, and David Arkin. MGM, 1973.

Lunes, Martes, Miyerkules, Huwebes, Biyernes, Sabado, Linggo [Monday, Tuesday, Wednesday, Thursday, Friday,

Saturday, Sunday]. Dir. Lino Brocka. Scriptwriter Orlando Nadres. Perf. Rafael Roco, Jr., Lolita

Rodriguez, Laurice Guillen, June Keithley, Maya Valdes, Bibeth Orteza, Lorli Villanueva, and Peque

Gallaga. Cinemanila, 1976.

Malvarosa. Dir. Gregorio Fernandez. Scriptwriter Consuelo P. Osorio. Perf. Charito Solis, Rebecca del Rio,

Leroy Salvador, Vic Silayan, Vic Diaz, Eddie Rodriguez, Carlos Padilla, Rey Ruiz, Johnny Reyes, Perla Bautista, and Caridad Sanchez. LVN, 1958.

Manila by Night. Dir. and scriptwriter Ishmael Bernal. Perf. Bernardo Bernardo, Cherie Gil, Rio Locsin, Charito Solis, William Martinez, Gina Alajar, Orestes Ojeda, Lorna Tolentino, Alma Moreno, Maya Valdes, Sharon Manabat, Johnny Wilson, and Jojo Santiago. Regal, 1980.

Maynila: Sa mga Kuko ng Liwanag [Manila: In the Claws of Darkness; literally, Manila: In the Talons of Light].

Dir. Lino Brocka. Scriptwriter Clodualdo del Mundo, Jr. Perf. Rafael Roco, Jr., Hilda Koronel, Tommy 
Yap, Tommy Abuel, Lou Salvador, Jr., Pio de Castro III, Lily Gamboa, Joonee Gamboa, Jojo Abella, Pancho Pelagio, Aning Bagabaldo, Danilo Posadas, and Lorli Villanueva. Cinema Artists, 1975. Menor de Edad [Underage]. Dir. Ishmael Bernal. Scriptwriter Franklin Cabaluna. Perf. Amy Austria, Chona

Castillo, Ana Marin, Rio Locsin, Sandy Andolong, Marilou Uson, Don Don Nakar, Vic Silayan, Marco Sison Ronald Bregendahl, Rustica Carpio, and Edmund Farolan. Seven Stars, 1979.

Miguelito: Ang Batang Rebelde [Miguelito: The Rebel Child]. Dir. Lino Brocka. Scriptwriter Jose Dalisay, Jr. Perf. Aga Muhlach, Eddie Garcia, Nida Blanca, Gloria Romero, Liza Lorena, Beth Bautista, Ronaldo Valdez, Robert Arevalo, Mario Montenegro, Ric Rodrigo, Delia Razon, Paquito Diaz, Rey PJ Abellana, Leni Santos, and Lito Pimentel. D’Wonder, 1985.

Moral. Dir. Marilou Diaz-Abaya. Scriptwriter Ricardo Lee. Perf. Lorna Tolentino, Gina Alajar, Sandy Andolong, Anna Marin, Juan Rodrigo, Michael Sandico, Mia Gutierrez, Lito Pimentel, Odette Khan, Dexter Doria, Laurice Guillen, and Ronald Bregendahl. Seven Stars, 1982.

Nashville. Dir. Robert Altman. Scriptwriter Joan Tewkesbury. Perf. Ronee Blakley, Karen Black, Keith Carradine, Geraldine Chaplin, Henry Gibson, Michael Murphy, Lily Tomlin, Barbara Harris, Shelley Duvall, Ned Beatty, Cristina Raines, Allen Garfield, Gwen Welles, Scott Glenn, and Keenan Wynn. Paramount, 1975.

Native Life in the Philippines. Dir. and scriptwriter Dean C. Worcester. Pan-American Film Mfg. Co., 1914. American Film Institute Catalog of Feature Films. 2007. 3 Apr. 2007 <http://www.afi.com/members/ catalog/AbbrView.aspx?s=1\&Movie=16266\&bhcp=1>.

Nunal sa Tubig [Mole on the Water]. Dir. Ishmael Bernal. Scriptwriter Jorge Arago. Perf. Elizabeth Oropesa, Daria Ramirez, George Estregan, Ella Luansing, Rustica Carpio, Nenita Jana, Lem Garcillano, and Leticia de Guzman. Crown Seven, 1976.

Orapronobis [Fight for Us]. Dir. Lino Brocka. Scriptwriter Jose F. Lacaba. Perf. Phillip Salvador, Gina Alajar, Dina Bonnevie, Abbo de la Cruz, Pen Medina, Ginnie Sobrino, Joel Lamangan, Gerard Bernschein, Ernie Zarate, Jess Ramos, Bon Vibar, Archie Adamos, Rene Hawkins, Ruben Rustia, Tess Dumpit, and William Lorenzo. Bernadette Associates and Special People, 1989.

Porky's. Dir. and scriptwriter Bob Clark. Perf. Dan Monahan, Mark Herrier, Wyatt Knight, Roger Wilson, Cyril O'Reilly, Tony Ganios, Kaki Hunter, Kim Cattrall, Nancy Parsons, Scott Colomby, Art Hindle, Susan Clark, and Alex Carras. 1981. DVD. 20 ${ }^{\text {th }}$ Century Fox, 2006.

Sybil. Dir. Daniel Petrie. Scriptwriter Stewart Stern. Perf. Joanne Woodward, Sally Field, Brad Davis, Martine Bartlett, Jane Hoffman, Charles Lane, and Natasha Ryan. 1976. DVD. Warner, 2006.

Syriana. Dir. and scriptwriter Stephen Gaghan. Perf. Kayvan Novak, George Clooney, Amr Waked, Christopher Plummer, Jeffrey Wright, Chris Cooper, Robert Foxworth, Nicky Henson, Nicholas Art, Matt Damon, Amanda Peet, Steven Hinkle, and Daisy Tormé. 2005. DVD. Warner, 2006.

The Three Faces of Eve. Dir. and scriptwriter Nunnally Johnson. Perf. Joanne Woodward, David Wayne, Lee J. Cobb, Edwin Jerome, Alena Murray, Nancy Kulp, Douglas Spencer, Terry Ann Ross, Ken Scott, Mimi Gibson, and Alistair Cooke. 1957. DVD. 20 ${ }^{\text {th }}$ Century Fox, 2004.

Tinimbang Ka Nguni't Kulang [You Were Weighed But Found Wanting]. Dir. Lino Brocka. Scriptwriter Mario O'Hara and Lino Brocka. Perf. Christopher de Leon, Lolita Rodriguez, Eddie Garcia, Gloria Romero, Mario O’Hara, Orlando Nadres, Laurice Guillen, Lilia Dizon, Hilda Koronel, Jay Ilagan, 
David

Primates in Paradise

Rosa Aguirre, Alicia Alonzo, Lily Miraflor, Joseph Sytangco, Ernie Zarate, Mely Mallari, and Estrella Kuenzler. Cinemanila, 1974.

Traffic. Dir. Steven Soderbergh. Scriptwriter Stephen Gaghan. Perf. Benicio del Toro, Jacob Vargas, Andrew Chavez, Michael Saucedo, Thomas Milian, Jose Yenque, Emilio Rivera, Michael O'Neill, Michael Douglas, Russell G. Jones, Luis Guzmán, Don Cheadle, Miguel Ferrer, Topher Grace, Erika Christensen, Catherine Zeta-Jones, Albert Finney, James Brolin, Steven Bauer, Amy Irving, Dennis Quaid, and Benjamin Bratt. 2000. DVD. Universal, 2002. 